\title{
Hybrid Membrane Bio-systems for Sustainable Treatment of Oil \& Gas Produced Water and Frac Flowback
}

\author{
Stephanie M. Riley ${ }^{1}$, Jean M.S. Oliveira ${ }^{2}$, Julia Regnery ${ }^{1}$, and Tzahi Y. Cath ${ }^{1}$ * \\ ${ }^{1}$ Colorado School of Mines, Golden, Colorado, USA \\ ${ }^{2}$ Federal University of Uberlandia, Uberlandia, Brazil
}

*Corresponding author: e-mail: tcath@mines.edu; phone: (303) 273-3402; fax: (303) 273-3413

A manuscript prepared for possible publication in

Separation and Purification Technology

June 8, 2016

(C) 2016. This manuscript version is made available under the Elsevier user license 


\begin{abstract}
Development of unconventional oil and gas $(\mathrm{O} \& \mathrm{G})$ resources through hydraulic fracturing has surged in recent years. While declines in oil prices have temporarily reduced spending towards research and development of innovative water management techniques, regulations and expected increase in freshwater demand and cost are intensifying competition among treatment providers to develop sustainable and efficient strategies for wastewater treatment and reuse. In this study, biologically active filtration (BAF), ultrafiltration, and nanofiltration were tested for the treatment of $\mathrm{O \& G}$ produced water $(\mathrm{PW})$ and fracturing flowback (FFB) wastewater. Results indicate that with seeding of microorganisms naturally present in PW, a resilient biofilm can develop that effectively removes organic matter from $O \& G$ waste streams. This serves as a pretreatment step for subsequent membrane desalination, mitigating membrane fouling. With thorough pretreatment, more than $99 \%$ of organic constituents and more than $94 \%$ of TDS can be removed, producing high quality permeate suitable for advanced reuse applications.
\end{abstract}

Keywords: produced water; biologically active filtration; ultrafiltration; nanofiltration; desalination; water reuse 


\section{Introduction}

\subsection{Unconventional oil and gas development in the U.S.}

Rapid development of unconventional oil and gas $(\mathrm{O} \& \mathrm{G})$ resources, especially shale gas and tight sands has been reshaping the energy landscape of the United States $[1,2]$. Despite recent drops in oil prices, hydraulic fracturing is forecasted to continue and accelerate [3]. However, this activity does not come without a concern-hundreds of thousands of gallons of clean water are required per well drilling and fracturing, $40 \%$ of which may return to the surface as fracturing flowback (FFB) [4]. Several weeks after fracturing is completed, the water that comes with $O \& G$ to the surface is mainly produced water $(\mathrm{PW})$, water naturally present in the $\mathrm{O} \& \mathrm{G}$ formations $[5,6]$. PW is highly variable in flowrate and composition and contains high concentrations of total dissolved solids (TDS), organic matter, and may contain residues of hydraulic fracturing chemicals [7,8]. Due to the challenging composition of PW, the lack of low-cost treatment technologies, and the current low price of $\mathrm{O} \& \mathrm{G}$, most operators prefer to dispose PW and FFB via Class II injection wells [3, 9]. While disposal wells offer a one-size-fits all solution, not all O\&G basins have access to them, and operators must treat or truck these streams to an injection site at relatively high costs $[5,10]$.

With limited volumes and increasing costs of fresh water resources, operators in the O\&G industry are searching for sustainable management practices, including treatment and reuse of PW and FFB. Potential reuse applications include irrigation, livestock watering, or hydraulic fracturing operations $[11,12]$. However, treatment of these streams is exceptionally challenging due to the complex and varying concentrations of constituents, such as TDS (ranging from $\sim 10,000 \mathrm{mg} / \mathrm{L}$ to more than $200,000 \mathrm{mg} / \mathrm{L}$ ), dissolved and free phase organic chemicals, heavy metals, and microorganisms [7, 8, 11]. Consequently, multi-barrier approaches are required to effectively treat O\&G waste streams for any beneficial reuse. Some technologies that have been applied in the past include hydrocyclones [13], dissolved-air flotation [14], electrocoagulation [15], membrane filtration [13, 16-18], oxidation [14, 19], and air stripping [20]. However, due to

the need for flexible, yet robust treatment schemes, and often a thorough pretreatment targeting removal of organic matter, the combinations of biological and membrane processes can be a successful approach to treating O\&G wastewaters. 


\subsection{Biological treatment}

Biological processes have proven effective at removing organic matter and nutrients from a variety of waste streams, including domestic wastewater [21], industrial wastewater [22, 23], and oily wastewaters [24]. Yet, one recognized limitation to efficient operation of biological treatment is high concentrations of TDS in the waste streams - commonly found in PW and FFB. Numerous studies have demonstrated a decline in dissolved organic carbon (DOC) degradation [25-30] and nitrification [27, 31-33] with increasing TDS concentration in bioreactors. However, one approach to accommodate the high TDS in the influent is through careful acclimation and seeding of the bioreactor with halophilic microbial communities. Results from research with halophilic microbial consortiums for treatment of PW have demonstrated varied success at the bench-scale [34-37]; yet, it may be unfavorable for full-scale implementation due to the high cost of seeding and difficulty to isolate strains that tolerate the variability of O\&G streams. Therefore, a robust biological treatment technology that supports a diverse microbial community is required that can degrade organic matter and nutrients under saline conditions and variable scales. Biologically active filtration (BAF) is a combined bio-physical process that might be capable of treating $O \& G$ waste streams, capitalizing on the nutrients and microorganisms already present in the streams while sustaining the growth of biofilm that can tolerate high/variable TDS concentrations.

BAF consists of filter media that supports biofilm attachment and growth; thus, it adsorbs contaminants, filters suspended solids, and efficiently removes and degrades nutrients and organic constituents [38-40]. BAF has been implemented in drinking water treatment facilities in the U.S. and Europe and is most recently being applied to municipal and industrial waste streams $[21,38,41-44]$. Biofilm in BAF may be engineered by isolation and seeding with selected microorganisms, or naturally developed with microorganisms present in the feed stream [21, 39, 45]. The biofilm consists of extracellular polymeric substances (EPS) and microorganisms that oxidize organic matter (readily available in PW and FFB), using the organic matter as carbon and energy sources to metabolize and produce new cells [45]. In order to maintain a steady biomass and effectively treat a waste stream, it is crucial that the BAF receives a constant supply of nutrients (i.e., carbon, oxygen, nitrogen, and phosphorous) [39, 40, 46].

Though several media types can be used to support BAF operation (e.g., sand, plastic carrier media, polystyrene beads), granular activated carbon (GAC) is most commonly used in the 
operation of BAF [47]. GAC is a very effective BAF media because of its extremely high specific surface area — one gram of GAC with a porosity of 0.5-0.8 has a surface area of 500$1,200 \mathrm{~m}^{2}$ [48]. The macroporous structure and rough surface of GAC create suitable sites for biofilm attachment and protection from sloughing or shear loss, in addition to enhanced adsorption capacity [49]. Numerous studies have validated the effectiveness of GAC for organic matter removal in various waste streams due to simultaneous adsorption and biodegradation [40, 47, 50-54]; however, hardly any studies have been conducted with GAC biofilters and real PW and FFB streams [55].

\subsection{Membrane treatment}

Membranes have long been used in the water, wastewater, food and beverage, pharmaceutical, and petroleum refining industries for the separation, concentration, or purification of liquid streams [56-61]. Ultrafiltration (UF), a low-pressure membrane process, is primarily used as a clarification or disinfection step to remove particles, turbidity, macromolecules, and microorganisms from impaired feed streams [62]. It often acts as a pretreatment step for membrane desalination processes such as nanofiltration (NF) or reverse osmosis (RO). NF is a pressure-driven membrane process capable of rejecting $>95 \%$ of divalent ions and lower rejection of monovalent ions, in addition to effective removal of other constituents in feed water such as low molecular weight organic matter. While UF has been studied for treatment of PW $[13,63,64]$ and NF/RO has success in desalination of pretreated PW [16, 65-69], studies that investigate dual-process UF-NF for treatment of PW are scarce.

For sustainable membrane treatment, optimizing water recovery, and reducing membrane fouling, it is critical to implement pretreatment processes that target removal of suspended and organic constituents. Therefore, the main objective of this study was to investigate the treatment of PW and FFB wastewaters from the Piceance and Denver-Julesburg (DJ) basins by a treatment train consisting of BAF pretreatment, UF polishing, and NF desalination. The main goal of the study was to determine the effectiveness of BAF as a pretreatment for subsequent membrane processes. Bench-scale experiments were conducted with three O\&G waste streams, specifically monitoring organic matter removal during BAF. In addition to organic matter removal, membrane performance was assessed by monitoring rejection of organic and inorganic 
constituents and by development of membrane fouling, expressed by permeate flux decline and changes in transmembrane pressure (TMP).

\section{Material and methods}

\subsection{Oil and gas feed waters}

Three types of O\&G wastewaters were used in this study, two PW streams collected from the Piceance and DJ Basins, and one FFB from the DJ Basin. Both PW streams were obtained several weeks after the hydraulic fracturing activity on the wells, minimizing the presence of fracturing fluid-related chemicals in the water. Conversely, FFB was obtained a few days after hydraulic fracturing, ensuring that the water quality of the sample was different than that of PW [6]. All wastewaters were acquired from separate well locations, providing increased variation in water chemistry. Concentrations of the main chemical constituents in each feed stream are summarized in Tables 1, 2, and 3.

\subsection{Biologically active filtration}

\subsubsection{Bench-scale system}

Bench-scale tests were conducted to investigate the degradation of organic matter and removal of turbidity by BAF. The BAF system consisted of six columns, two columns operated in parallel, termed System A (columns designated BAF 1 and BAF 2), and four columns operated in parallel or series, termed System B (columns designated BAF 3, BAF 4, BAF 5, and BAF 6). Columns in System A were always treated as duplicates and were operated under identical operating conditions and with the same feed waters, as described in Section 2.2.2.2. The columns in System B were operated in parallel during aeration optimization tests and in series during FFB treatment experiments (see description in Section 2.2.2). Each column is $5 \mathrm{~cm}$ in diameter and $147 \mathrm{~cm}$ tall, with GAC occupying $76 \mathrm{~cm}$ at the bottom of each column. The columns were packed with spent GAC media (i.e., previously used in BAF of surface water) that was acquired from the Peter D. Binney Water Purification Facility (Aurora Water, Aurora, Colorado). Prior to filling the columns, the GAC was heated to $150{ }^{\circ} \mathrm{C}$ for $16 \mathrm{hrs}$ to deactivate microorganisms that existed on the media, yet keeping organic matter adsorbed to the GAC. A feed tank of 10 L capacity was connected to each column, and the feed water was circulated with a multi-head peristaltic pump (Cole-Parmer, Court Vernon Hills, IL) between the tanks and the 
columns, flowing upward in the columns. Backwash ( $\sim 50 \%$ bed expansion) was performed for approximately 30 minutes at the end of each experiment or whenever the inlet pressure exceeded $35 \mathrm{kPa}$ (5 psi). Aeration was provided in the feed tank or column inlet (bottom), depending on the desired conditions for each test, and was controlled via in-line flow rotameters.

The BAF system was operated in either batch or continuous-mode. During batch-mode operation, feed water was circulated between a tank and a column in a closed loop, altering conditions (i.e., flow and aeration rates) according to the purpose of each experiment; thus, reducing the concentration of organic matter over time. In continuous-mode operation, illustrated in Fig. 1a, PW or FFB was continuously dosed into the system and was diluted with BAF-treated water that was constantly recirculating between the feed tank and column/s. In continuous mode operation, the effluent is removed from the feed tank at the same rate that PW or FFB is dosed into the system, maintaining constant volume of water in the system. Hydraulic retention time (HRT) and GAC volume are the key parameters varied during the experiments to optimize process efficiency. HRT in this study varied from 3.7 to $20 \mathrm{hrs,} \mathrm{while} \mathrm{GAC} \mathrm{depth} \mathrm{was} 76$ or 304 $\mathrm{cm}$.
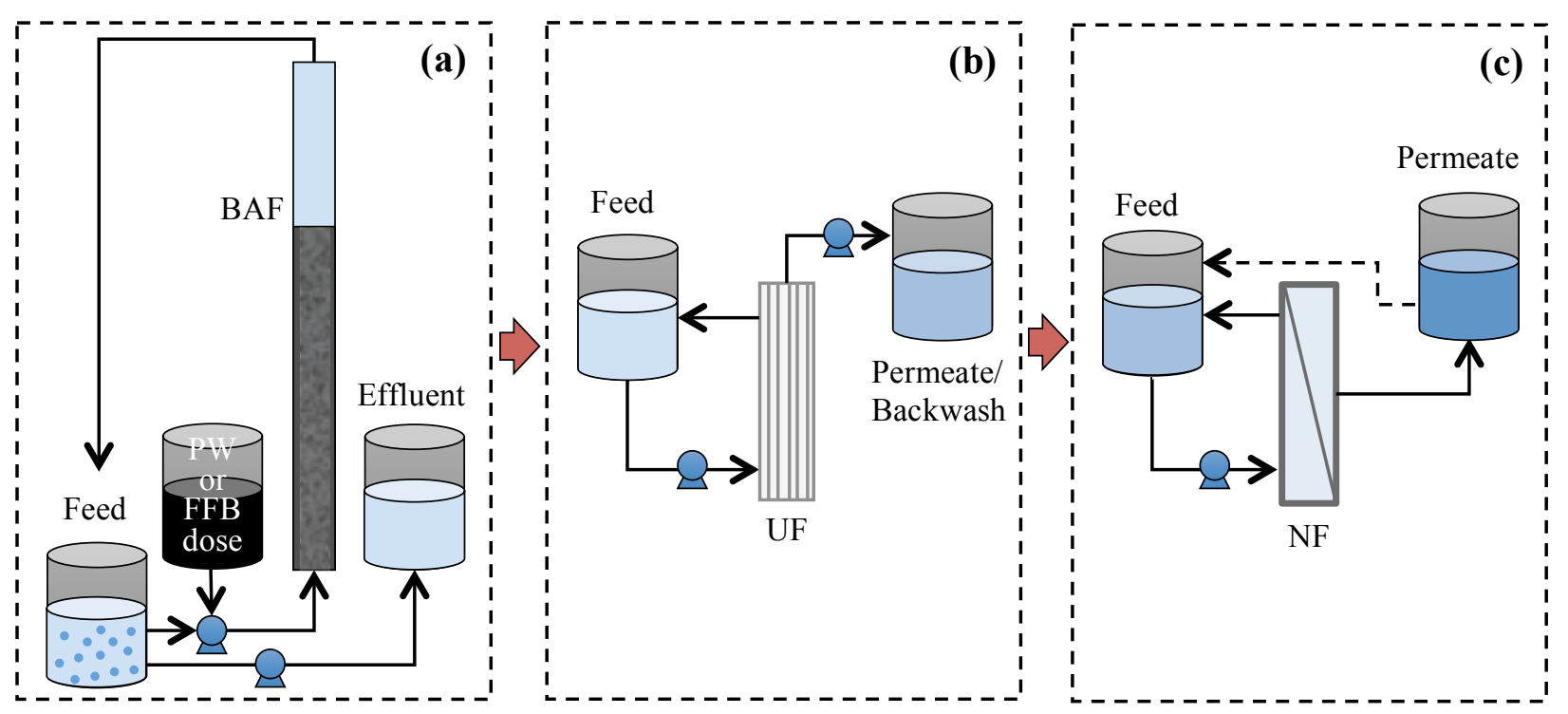

Fig. 1. Flow diagram of the BAF-UF-NF system. (a) PW or FFB is treated by BAF in continuous-mode (shown here, with dosing of raw PW or FFB) or batch-mode, followed by (b) $\mathrm{UF}$, and (c) NF desalination.

\subsubsection{BAF experimental procedures}

\subsubsection{BAF column acclimation}


The first series of experiments with System A were conducted to gradually develop and acclimate a biofilm consisting of microorganisms naturally occurring in the PW. System A was operated in batch-mode with columns in parallel, at a hydraulic loading rate (HLR) of $2.44 \mathrm{~m} / \mathrm{hr}$ $\left(1.0 \mathrm{gpm} / \mathrm{ft}^{2} / 83 \mathrm{~mL} / \mathrm{min}\right.$ feed flowrate). The feed tank for each column contained a $10 \mathrm{~L}$ batch of DJ basin PW at ambient temperature of $\sim 22{ }^{\circ} \mathrm{C}$, and it was aerated at a rate of $0.5 \mathrm{~L} / \mathrm{min}$ ambient air. Experiments were repeated under the same conditions to determine if DOC degradation improves over time.

\subsubsection{Continuous-mode}

After the biofilm was acclimated, System A was operated in continuous-mode, as illustrated in Fig. 1a, to simulate conditions at commercial-scale operation. Three types of feed water were tested: Piceance basin PW (7 mL/min raw feed dose, $24 \mathrm{hr}$ system HRT), DJ basin PW (3.5 $\mathrm{mL} / \mathrm{min}$ raw feed dose, $48 \mathrm{hr}$ system HRT), and DJ basin FFB (3.5 mL/min raw feed dose, $48 \mathrm{hr}$ system HRT). System HRT refers to the time the water remains in the system (columns and feed tank), while column HRT represents the time the water is in contact with the GAC. 24 and $48 \mathrm{hr}$ system HRTs resulted in column HRTs of 3.7 and $7.4 \mathrm{hr}$, respectively. Experiments with the Piceance basin PW were operated at a lower system HRT due to its lower organic matter concentration. The $10 \mathrm{~L}$ holding tank for each column was operated under the same conditions as during biofilm conditioning. The effluent of each water type was collected for analysis and subsequent treatment by UF.

To further evaluate the treatment of DJ FFB, an additional experiment was performed using System B (previously acclimated with PW) with four columns connected in series. This increased the column HRT to $20 \mathrm{hrs}$, while the system HRT remained at $48 \mathrm{hrs}$. BAF-3 and BAF-5 were aerated in the column inlet (bottom), and the aeration conditions were determined during aeration optimization tests.

\subsubsection{Aeration optimization}

Aeration optimization tests were conducted to determine the impact of dissolved oxygen (DO) concentration on DOC removal rates and effluent turbidity. System B was operated under similar batch conditions as described in Section 2.2.2.1, except with alterations in aeration. 
Aeration in BAF 3 was provided in the feed tank $(0.5 \mathrm{~L} / \mathrm{min})$, while air for the other columns was provided at the column inlet (BAF 4: $0.05 \mathrm{~L} / \mathrm{min}$, BAF 5: 0.1 L/min, BAF 6: $0.25 \mathrm{~L} / \mathrm{min}$ ).

\subsection{Ultrafiltration}

\subsubsection{Membranes}

Two capillary UF membranes, each having pores $0.03 \mu \mathrm{m}$ in diameter, were tested in outside-in flow configuration. These include polyvinylidene fluoride (PVDF) fibers $(2.2 \mathrm{~mm}$ outside diameter) from Dow Chemical Company (Midland, MI), referred to as PVDF1, and PVDF fibers (2.6 mm outside diameter) from Koch Membrane Systems (Wilmington, MA), referred to as PVDF2. PVDF is a favorable material for capillary membranes in membrane bioreactors due to their chemical resistance (e.g., chlorine and $\mathrm{pH}$ tolerance), mechanical strength, and durability [70, 71]. The PVDF fibers' ability to withstand high concentrations of organic matter makes it a suitable candidate for PW and FFB treatment.

\subsubsection{Bench-scale system}

Bench-scale tests were performed to determine water flux, permeability, turbidity and TOC rejection, and fouling tendency of the UF membranes. Membrane modules were custom-made in the lab using $1.27 \mathrm{~cm}$ clear PVC pipe as a pressure vessel and were stored in deionized water at 5 ${ }^{\circ} \mathrm{C}$ until testing. Each module was potted with five $30.5 \mathrm{~cm}$ long fibers (membrane area: PVDF1 $=104 \mathrm{~cm}^{2}, P V D F 2=125 \mathrm{~cm}^{2}$ ) to maintain similar flow patterns in each.

A flow schematic of the UF bench-scale apparatus is illustrated in Fig. 1b. A feed reservoir of $25 \mathrm{~L}$ capacity was connected to a gear pump (Micropump, Inc., Vancouver, WA) that circulated the feed water through the membrane module at $1.4 \mathrm{~L} / \mathrm{min}(20 \mathrm{~cm} / \mathrm{s})$. An $8 \mathrm{~L}$ permeate tank was positioned on an analytical balance (Denver Instrument, Bohemia, NY) that was connected to a SCADA system (LabVIEW, National Instruments, Austin, TX; and UE9, LabJack Corporation, Lakewood, $\mathrm{CO}$ ) for recording of the permeate mass and calculation of water flux. A peristaltic pump (Cole-Parmer, Court Vernon Hills, IL) on the permeate side of the membrane was used to draw permeate (by vacuum) and induce backwashing through the membranes. Feed temperature was maintained at $20 \pm 0.5^{\circ} \mathrm{C}$ using an immersed heater controlled by a temperature probe (LabJack EI1034, Lakewood, CO) connected to the SCADA system. 


\subsubsection{Experimental procedures}

\subsubsection{Permeability tests}

Batch experiments with BAF-treated PW and FFB and PVDF membranes were performed utilizing new membrane modules to evaluate membrane fouling and rejection. To ensure unbiased results and evaluate the integrity of the membranes (i.e., water flux and turbidity rejection), permeability tests were conducted with each module prior to testing. Permeability tests were conducted with Milli-Q water mixed with bentonite to a target turbidity of 12-15 NTU, and consisted of constant flux experiments ranging from 10 to $50 \mathrm{~L} / \mathrm{m}^{2} / \mathrm{hr}(\mathrm{LMH})$ in 10 LMH increments and lasting $10 \mathrm{~min}$ each. Rejection was determined through turbidity measurement. Modules were replaced if the permeability and rejection varied by more than $10 \%$ for each membrane type; the baseline was previously determined by averaging results from three modules (PVDF1: 2.28 LMH/kPa, PVDF2: 9.01 LMH/kPa). The critical flux (i.e., permeate flux above which irreversible fouling occurs) was determined for each feed stream and membrane by conducting a permeability test with the BAF-treated feed. Results were used to determine the operating flux for the fouling tests.

\subsubsection{Fouling tests}

PVDF1 and PVDF2 were tested with BAF-treated streams (Piceance basin PW, DJ PW, and DJ FFB). Experiments were conducted at the average critical flux determined with all water types, $\sim 26 \mathrm{LMH}$ for PVDF1 and $38 \mathrm{LMH}$ for PVDF2, with a $20 \mathrm{~cm} / \mathrm{s}$ feed cross-flow velocity. Each $10 \mathrm{~L}$ feed batch was treated until $\sim 90 \%$ water recovery was achieved. Backwashing with UF permeate was performed every $5 \mathrm{~min}$ for $36 \mathrm{sec}$, at $150 \mathrm{LMH}$ for PVDF1 and $80 \mathrm{LMH}$ for PVDF2. Backwash flux was determined per the recommended maximum backwash flux for each membrane.

\subsection{Nanofiltration}

\subsubsection{Membranes}

Polyamide flat sheet NF membranes (NF90) from Dow Filmtec (Midland, MI) were tested in this study. Previous studies have investigated this membrane for treatment of municipal wastewater [60] and PW [25], demonstrating its ability to withstand harsh and varying conditions (e.g., organic matter and TDS). To distinguish fouling from compaction during experiments, 
membranes were first compacted for 20 hours. After compaction, membrane integrity was evaluated by rejection tests with a $2 \mathrm{~g} / \mathrm{L} \mathrm{NaCl}$ feed solution. Membranes were replaced if the rejection or water flux varied by more than $10 \%$ for a given pressure. Similar to UF, the baseline was determined by averaging results from three membranes. New membrane coupons were installed for each O\&G wastewater pressure test to evaluate membrane performance and sustainability (i.e., water flux, contaminant rejection, turbidity removal, and fouling propensity).

\subsubsection{Bench-scale system}

The bench-scale apparatus consisted of a cross-flow membrane cell having a membrane active area of $139 \mathrm{~cm}^{2}$. A 34 mil spacer was installed on the feed side and tricot spacers were installed on the permeate side. A flow schematic of the NF bench-scale system is illustrated in Fig. 1c. A $10 \mathrm{~L}$ feed tank was connected to a positive displacement pump (Hydra-cell M03, Wanner Engineering Inc., Minneapolis, MN) that circulated the feed water through the test cell at $1.2 \mathrm{LPM}$, equivalent to a $14 \mathrm{~cm} / \mathrm{s}$ cross-flow velocity. Permeate was collected in a $500 \mathrm{~mL}$ tank and was returned to the feed tank intermittently to maintain constant feed concentration. A SCADA system similar to that of the bench-scale UF system (LabVIEW, National Instruments, Austin, TX; and UE9, LabJack Corporation, Lakewood, CO) was used to control operating conditions (i.e., feed temperature, feed pressure, and permeate volume), collect experimental data (i.e., feed conductivity, permeate conductivity (Cole-Parmer, Court Vernon Hills, IL), and record water level in the permeate tanks, which was used to automatically calculate water flux).

\subsubsection{Experimental procedures}

Batch experiments with UF-treated PWs and FFB were performed at varying pressures to evaluate rejection, water flux, and fouling propensity. Feed batches of $5 \mathrm{~L}$ were recirculated through the system under constant pressure of 1035, 1380, 1725, or $2070 \mathrm{kPa}(150,200,250$, and $300 \mathrm{psi}$ ) and temperature of $20 \pm 0.2{ }^{\circ} \mathrm{C}$. Three $20 \mathrm{hr}$ experiments were conducted at each pressure. After the first $20 \mathrm{hr}$ test, the membrane was cleaned and the experiment was resumed for another $20 \mathrm{hrs}$ with the same feed batch to evaluate flux recovery after initial fouling. After the second $20 \mathrm{hr}$ test, the feed was replaced with a new batch to further evaluate the fouling propensity and performance of the membrane. This experimental procedure was performed for all water types. 


\subsubsection{Membrane cleaning}

Membrane cleanings were performed after the first $20 \mathrm{hr}$ fouling test for each pressure and water type. The test cell was removed from the system and $0.1 \mathrm{M} \mathrm{NaOH}$ solution was circulated on the feed side of the membrane for $45 \mathrm{~min}$, followed by another 45 min circulation of $0.1 \mathrm{M}$ $\mathrm{HCl}$ solution, and a 15 min rinse with deionized water to remove residual chemicals.

\subsection{Sampling and analytical procedures}

Raw feed water, BAF column effluent, UF permeate, and NF permeate samples were collected to track the removal of organic and inorganic constituents during each treatment stage. Analysis of wastewater relevant parameters was conducted according to Standard Methods [72]. Temperature, DO (BAF only) (YSI 55, Yellow Springs, OH), pH (Oakton Instruments, Vernon Hills, IL), and turbidity (2100N Turbidimeter, Hach, Loveland, CO) were measured immediately after sample collection and then samples were stored at $5{ }^{\circ} \mathrm{C}$ for subsequent analyses. Samples for DOC analysis (Shimadzu TOC-L, Columbia, MD) were filtered through a $0.45 \mu \mathrm{m}$ polyethersulfone (PES) filter and were acidified with concentrated $\mathrm{HCl}$ prior analysis. Samples for chemical oxygen demand (COD) (Hach, Loveland, CO) analysis were diluted as necessary to avoid chloride interferences $(2000 \mathrm{mg} / \mathrm{L})$. Ion chromatography (IC; ICS-90, Dionex, Sunnyvale, CA) and inductively coupled plasma - atomic emission spectroscopy (ICP-AES; Optima 5300, Perkin-Elmer, Fremont, CA) analyses were conducted on all samples to determine the concentration of major anions and cations, respectively. The sum of ion concentrations was also used for determination of TDS concentration of the streams. All samples were diluted with MilliQ water to reduce sodium and chloride concentrations to below $500 \mathrm{mg} / \mathrm{L}$, and ICP-AES samples were acidified with nitric acid to a $\mathrm{pH}$ of 2.

In addition, three-dimensional fluorescence excitation-emission matrix (3D EEM) analyses were performed using the Aqualog spectrofluorometer (Horiba, Edinson, NJ) to characterize the dissolved organic matter fraction in the BAF feed, BAF effluent, UF permeate, and NF permeate of the DJ FFB stream. Analytical procedures similar to those described by Stahlschmidt et al. [73] were followed to record 3D EEMs. Samples were filtered and diluted to a DOC concentration of $2 \mathrm{mg} / \mathrm{L}$ to reduce quenching of fluorescence. The excitation wavelength was scanned from 240 to $800 \mathrm{~nm}$ with increments of $3 \mathrm{~nm}$, covering the emission spectra from 250 to 
$832 \mathrm{~nm}$ at $2.33 \mathrm{~nm}$ (4 pixel) increments. A blank EEM was acquired under the same conditions with Milli-Q water used to dilute samples and was subtracted from all sample spectra to remove influence of Raman scattering. Corrections for the inner filter effect and Raleigh scattering were applied within the Aqualog software. All recorded 3D EEMs were multiplied by their respective dilution factor and normalized to Raman Units (RU) to allow for comparison of fluorescence intensities across samples.

\section{Results and discussion}

\subsection{BAF column acclimation}

Experiments were performed in batch-mode with DJ basin PW to evaluate the ability of microorganisms to acclimate to PW over time. System A was operated for several weeks, with feed batches replaced once the DOC concentration in the BAF effluent reached $25 \mathrm{mg} / \mathrm{L}$, after which minimal degradation of DOC was observed. Average effluent DOC concentration as a function of time is shown in Fig. 2. During the first week, the DOC concentration in the BAF effluent was above $25 \mathrm{mg} / \mathrm{L}$ until $60 \mathrm{hrs}$ of treatment. In subsequent weeks, the DJ basin PW batches reached $25 \mathrm{mg} / \mathrm{L} \mathrm{DOC}$ in a shorter time $(36,34$, and $25 \mathrm{hrs}$ for the third, fourth, and fifth week batches, respectively). After the fifth week, the treatment time remained constant. The increased DOC degradation rate from the first to fourth week suggest that microorganisms became acclimated to the PW. In a previous study with biological treatment of high salinity wastewater, microorganisms previously acclimated to high salt concentrations performed better in removing COD (a surrogate for DOC) than those not acclimated [74], indicating that acclimation has notable impact on the degradation efficiency of organic matter. To support the concept of improved DOC removal efficiency through biomass acclimation, Hoang et al. demonstrated that the growth and stabilization of biomass may take up to four weeks of system operation [40]. 


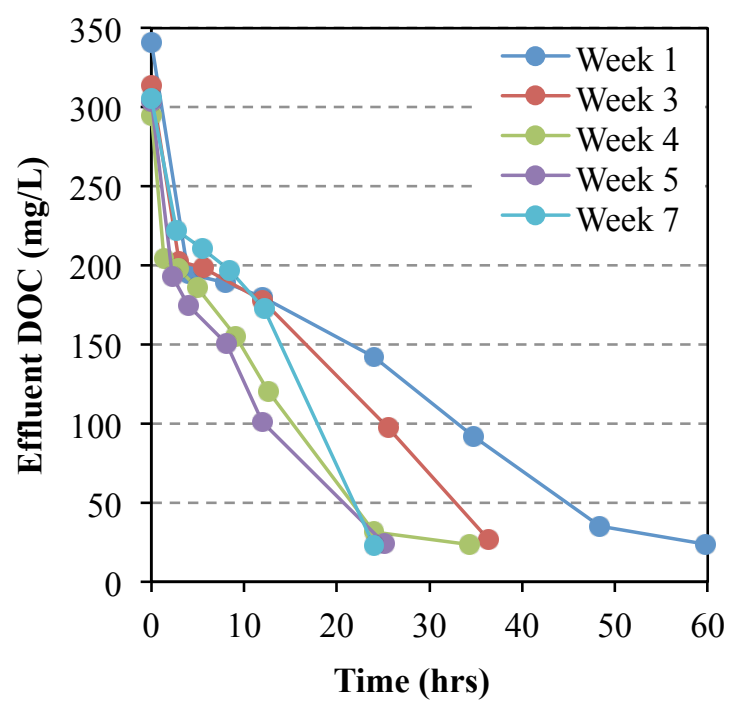

Fig. 2. Average effluent DOC concentration as a function of time for the two columns of System A operated in batch mode with DJ basin PW feed (14.6 g/L TDS). $10 \mathrm{~L}$ batches were used per filter and experiments were conducted under ambient temperature $\left(\sim 22^{\circ} \mathrm{C}\right)$ with a $2.4 \mathrm{~m} / \mathrm{hr} \mathrm{HLR}$.

Similar to trends in other studies utilizing GAC for BAF [40, 47, 75], adsorption was the dominant process during the first 4 hours, demonstrated by the rapid decline in DOC concentration in each experiment, followed by a longer period of slow biodegradation. The adsorption and biodegradation trends are reinforced by Freedman's study utilizing a similar BAF system to treat DJ basin PW [55]. Freedman compares DOC removal among three types of aerated columns: one with GAC (biologically active), one without GAC, and one abiotic with GAC (no biological activity). This enables the isolation of adsorption, air stripping, and biodegradation removal mechanisms. Freedman correlates the initial, sharp decline in DOC to adsorption, with the remainder dominated by biodegradation. Results from week 7 demonstrate decreased adsorption and increased biodegradation rates, indicating that the adsorption capacity of the GAC decreased and that the microorganisms became acclimated to the PW. Hoang et al. further revealed that the majority of the adsorbed compounds from a low strength synthetic wastewater are non-biodegradable, low molecular weight organic matter [47]. Zhao et al. observes the degradation of high molecular weight organic matter from oil-field wastewater in fluidized bioreactors [76]. This suggests that the $\sim 25 \mathrm{mg} / \mathrm{L}$ recalcitrant DOC in the BAF effluent may be non-biodegradable low molecular weight organic matter. 


\subsection{Piceance basin produced water treatment}

\subsection{1. $B A F$}

Continuous-mode testing of System A was used to evaluate the resilience and efficiency of the biofilm over time with continuous exposure to raw PW. The raw Piceance basin PW (lower DOC concentration) was dosed to maintain a $24 \mathrm{hr}$ system HRT (3.7 hr column HRT). DOC, DO, and COD results are presented in Fig. 3. The system reached steady state after $5 \mathrm{hrs}$ of continuous-mode operation with an average effluent DOC concentration of $11 \mathrm{mg} / \mathrm{L}(67 \%$ removal). System A also removed approximately $75 \%$ of the influent COD. Similar organic matter removal was achieved in a fluidized bioreactor utilizing polymeric media during continuous-mode operation with low-salinity oil-field wastewater [76, 77]. The decline in DO concentration suggests an increase in microbial activity as DO gets consumed during continuous biodegradation of DOC in the system. The results indicate that the microorganisms can withstand constant exposure to saline Piceance basin PW and maintain steady performance. The majority of organic matter was removed, producing effluent suitable for subsequent membrane treatment.

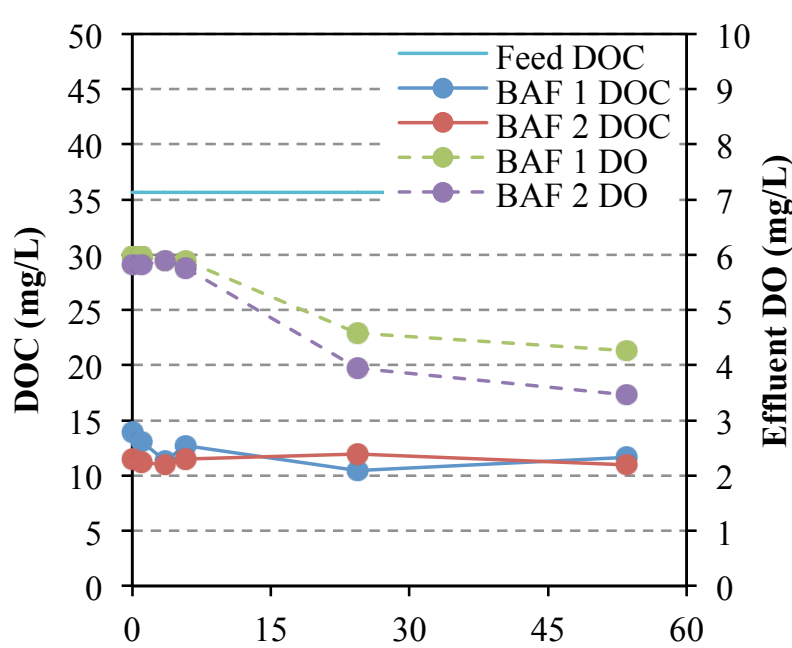

(a)

Time (hrs)

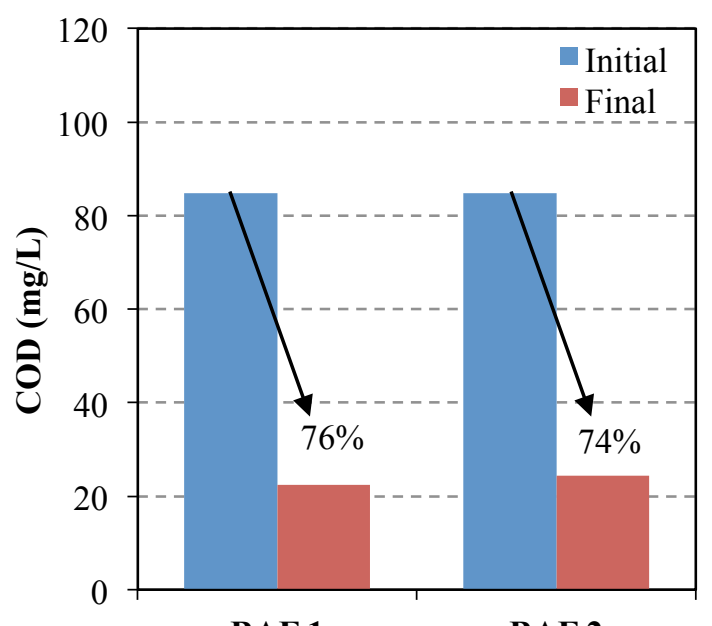

(b)
BAF $1 \quad$ BAF 2

Fig. 3. System A (a) DOC and DO concentration as a function of time and (b) initial and final COD concentrations with percent removal for continuous-mode Piceance basin PW experiments (12.6 g/L TDS). Operating conditions: $10 \mathrm{~L}$ feed volume, $3.7 \mathrm{hr}$ column HRT, $24 \mathrm{hr}$ system HRT, ambient temperature $\left(\sim 22^{\circ} \mathrm{C}\right)$, and $2.4 \mathrm{~m} / \mathrm{hr}$ HLR. 


\subsection{2. $U F$}

Experiments were conducted with BAF-treated Piceance basin PW feed (12.6 g/L TDS, 10 mg/L DOC, 1.25 NTU) and PVDF membranes to evaluate membrane performance (i.e., water flux, turbidity removal, and DOC removal) and fouling propensity. Membrane modules were operated until $90 \%$ recovery of a $10 \mathrm{~L}$ feed batch, with permeate backwashing performed every 5 min. PVDF1 was operated at $\sim 26 \mathrm{LMH}$, while PVDF2 was operated at $\sim 38 \mathrm{LMH}$, as previously determined during critical flux tests. Permeability and TMP as a function of time are illustrated in Fig. 4 for PVDF1 and PVDF2. Minimal changes in permeability and TMP were observed in both membranes, indicating negligible fouling and membrane stability. Although PVDF1 was less permeable than PVDF2, with a water permeability approximately three times lower than PVDF2 $(\sim 2.17 \mathrm{LMH} / \mathrm{kPa})$ and a TMP twice that of PVDF2 ( 13.8 $\mathrm{kPa}$ (2 psi)), BAF pretreatment was still effective for removal of most organic foulants. PVDF1 reduced permeate turbidity to $0.2 \mathrm{NTU}$ and PVDF2 produced permeate of $0.1 \mathrm{NTU}$, suitable for NF treatment.

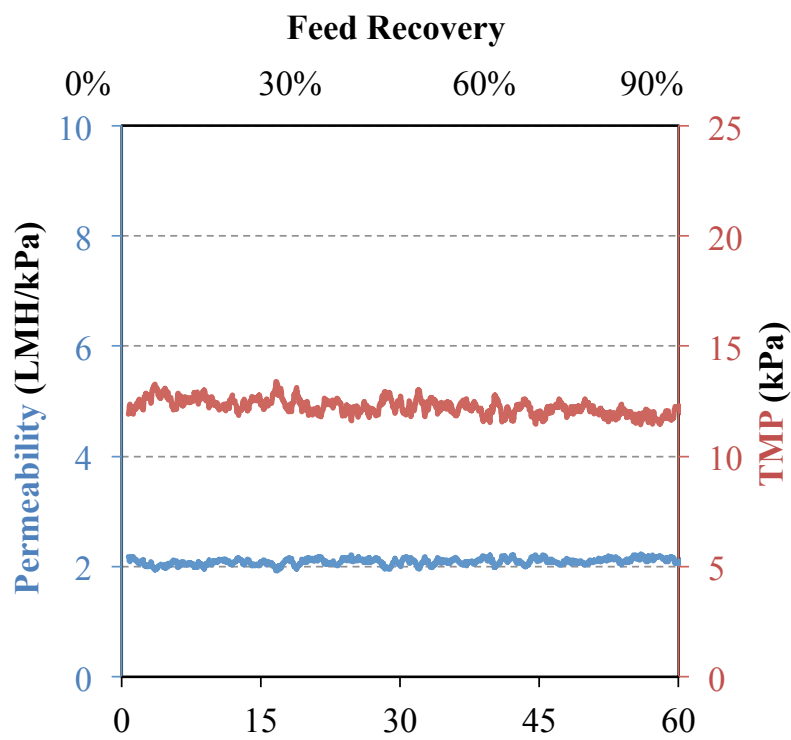

(a) Time (hrs)

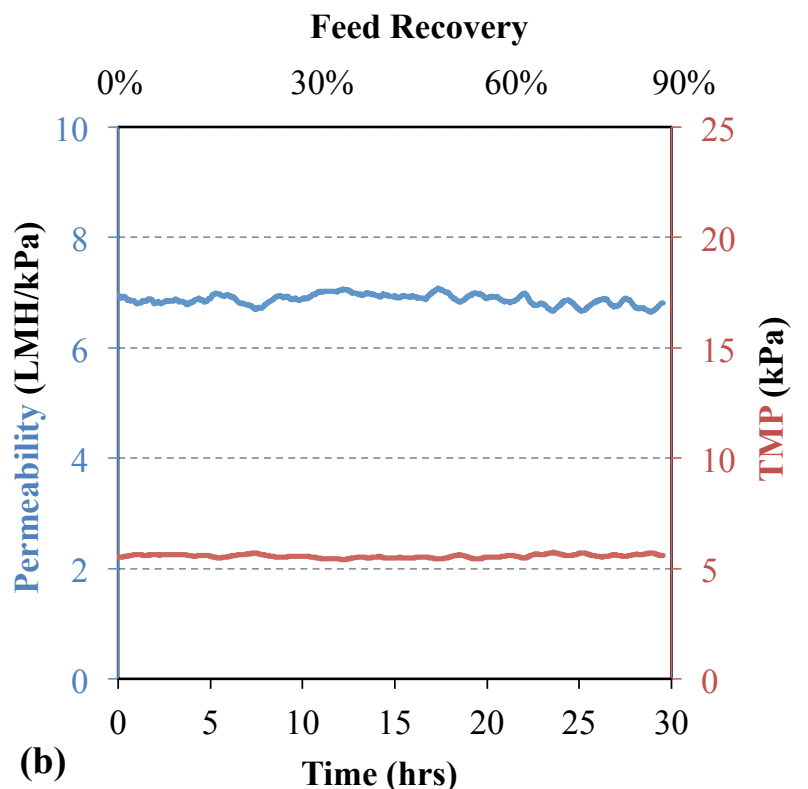

Fig. 4. Membrane permeability and TMP as a function of time for (a) PVDF1 and (b) PVDF2 UF membranes tested with BAF-treated Piceance basin PW (12.6 g/L TDS, $10 \mathrm{mg} / \mathrm{L}$ DOC, and 1.25 NTU turbidity). PVDF1 was operated at $26 \mathrm{LMH}$ and PVDF2 was operated at $38 \mathrm{LMH}$. Backwash was performed every $5 \mathrm{~min}$ for $36 \mathrm{sec}$ at $150 \mathrm{LMH}$ for PVDF1 and $80 \mathrm{LMH}$ for PVDF2. 


\subsection{3. $N F$}

NF membrane fouling experiments with pretreated Piceance basin PW were conducted to determine the effectiveness of BAF and UF pretreatment. Permeate flux as a function of time and permeate quality for all fouling tests are presented in Fig. 5. The test at $1035 \mathrm{kPa}$ (150 psi) TMP resulted in the lowest membrane fouling. Water flux stabilized at approximately $10 \mathrm{LMH}$, even after replacing the feed and introducing additional foulants to the system. As expected, this test also had the lowest solute rejection (83\% DOC, 67\% total nitrogen (TN), and 87\% TDS). The NF test conducted at $1380 \mathrm{kPa}$ (200 psi) TMP demonstrated similar trends, with water flux stabilizing near $18 \mathrm{LMH}$ and slightly higher DOC, TN, and TDS rejection. Like other studies $[65,78]$, the NF tests conducted at 1725 and $2070 \mathrm{kPa}$ (250 and $300 \mathrm{psi}$ ) TMP had the highest water flux and solute rejection (with exception of TDS at $1725 \mathrm{kPa}$ (250 psi)), but also experienced more considerable flux decline, making operation at these pressures less sustainable. It should be noted that TDS rejection during the $1725 \mathrm{kPa}$ (250 psi) test was lower than expected due to insufficient membrane compaction prior to experimentation, as revealed in Fig. $5 \mathrm{~b}$ and Table 1. Nonetheless, the expected trends of increased rejection with transmembrane pressure (due to permeation) are reflected in experiments with DJ PW and DJ FFB.
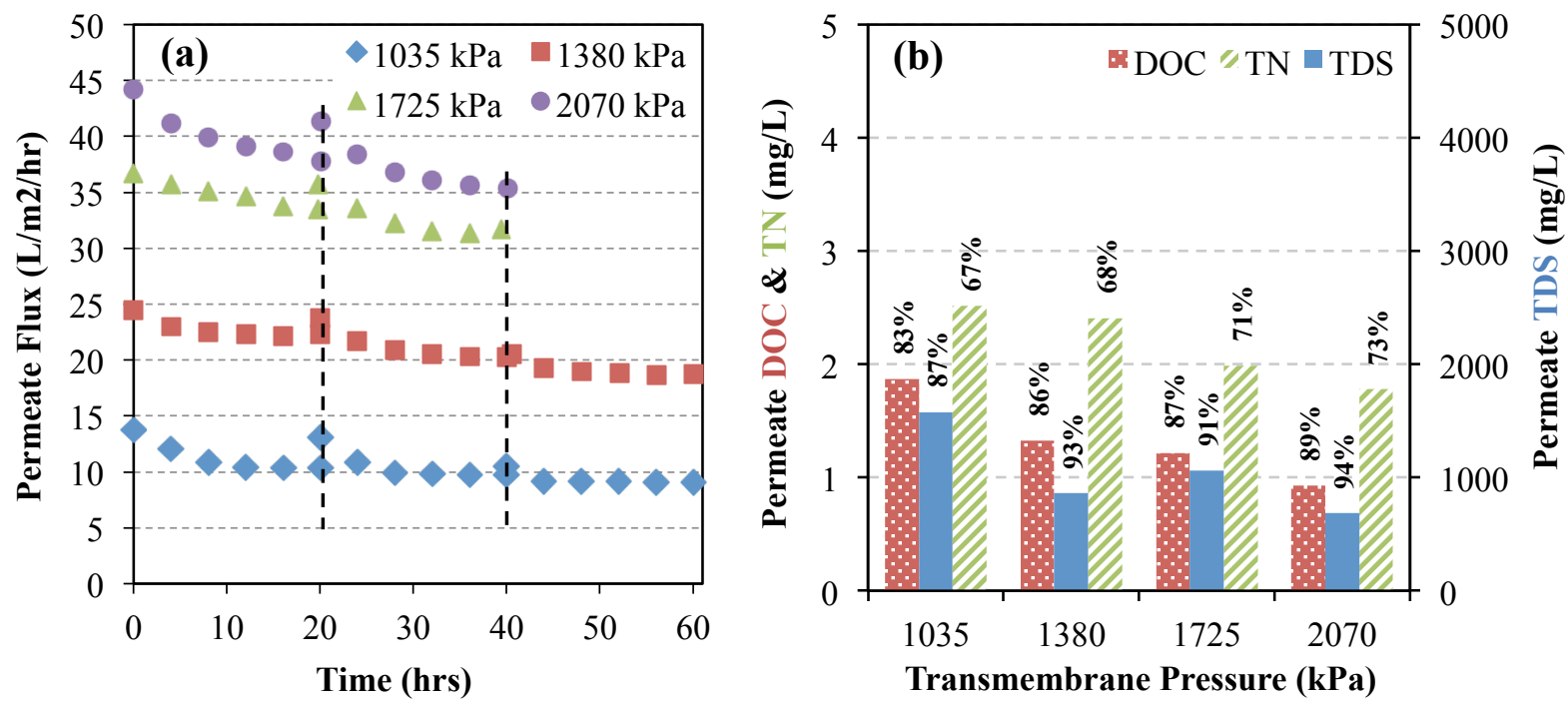

Fig. 5. Results from NF experiments with BAF/UF pretreated Piceance basin PW (12.3 g/L TDS, $9.6 \mathrm{mg} / \mathrm{L} \mathrm{DOC}, 7.3 \mathrm{mg} / \mathrm{L} \mathrm{TN}, 0.9 \mathrm{NTU}$ turbidity). (a) Water flux as a function of time and corresponding (b) permeate concentrations and percent rejection of DOC, TN, and TDS as a function of TMP (1035 kPa (150 psi), $1380 \mathrm{kPa}(200 \mathrm{psi}), 1725 \mathrm{kPa}(250 \mathrm{psi}), 2070 \mathrm{kPa}(300$ psi)). Membrane cleanings after $20 \mathrm{hrs}$ and feed replacement after $40 \mathrm{hrs}(1035$ and $1380 \mathrm{kPa}$ tests) are denoted by dashed lines. 
Results from BAF, UF, and NF indicate that the treatment train was effective at removing organic and inorganic constituents from the Piceance basin PW, meeting recommended standards for livestock watering and stream flow augmentation in most cases [8, 79], and definitely suitable for hydraulic fracturing. As summarized in Table 1, the majority of organic constituents were removed by BAF pretreatment, with very little removed by UF, and further removal of DOC with increasing pressure during NF desalination. BAF was also effective for some turbidity removal, with the majority of turbidity removed during UF and slight reductions attained during NF. Conversely, most inorganic compounds are not rejected until NF, with minimal rejection of multivalent ions achieved during UF. General trends indicate an increase in rejection with NF pressure, achieving over 94\% TDS rejection (685 mg/L permeate) at $2070 \mathrm{kPa}(300 \mathrm{psi})$. Results from NF experiments indicate that BAF followed by UF was an effective pretreatment, minimizing fouling and enabling sufficient desalination of Piceance basin PW.

Table 1. Heat map summarizing the characteristics of the Piceance basin PW after BAF, UF, and NF treatment. Red denotes higher concentrations, while green represents lower concentrations. Color shades are evenly distributed between maximum (dark red) and minimum (dark green) values for each constituent. All units are $\mathrm{mg} / \mathrm{L}$ unless otherwise noted.

\begin{tabular}{|c|c|c|c|c|c|c|c|}
\hline \multirow[b]{2}{*}{ Analyte } & \multicolumn{3}{|c|}{ Pretreatment } & \multicolumn{4}{|c|}{ NF Permeate } \\
\hline & $\begin{array}{l}\text { Raw } \\
\text { Feed }\end{array}$ & $\begin{array}{l}\text { BAF effluent } \\
\text { (UF feed)** }\end{array}$ & $\begin{array}{c}\text { UF perm } \\
(\mathrm{NF} \text { feed })^{* *}\end{array}$ & $\begin{array}{l}1035 \\
\mathrm{kPa}\end{array}$ & $\begin{array}{l}1380 \\
\mathrm{kPa}\end{array}$ & $\begin{array}{l}1725 \\
\mathrm{kPa} \\
\end{array}$ & $\begin{array}{l}2070 \\
\mathrm{kPa}\end{array}$ \\
\hline Turbidity (NTU) & 4.12 & 1.25 & 0.150 & 0.104 & 0.087 & 0.064 & 0.066 \\
\hline COD & 84.8 & 23.4 & 15.5 & BDL* & BDL* & BDL* & BDL* \\
\hline DOC & 35.6 & 9.90 & 9.59 & 1.87 & 1.33 & 1.22 & 0.93 \\
\hline $\mathrm{TN}$ & 15.1 & 11.5 & 7.29 & 2.52 & 2.41 & 1.99 & 1.78 \\
\hline $\mathrm{B}$ & 12.0 & 12.0 & 10.3 & 10.2 & 7.93 & 7.94 & 6.36 \\
\hline $\mathrm{Ba}$ & 38.1 & 38.1 & 6.41 & 0.053 & 0.049 & 0.093 & 0.008 \\
\hline $\mathrm{Ca}$ & 180 & 180 & 50.1 & 0.464 & 0.029 & 0.058 & 0.000 \\
\hline $\mathrm{K}$ & 32.7 & 32.7 & 30.3 & 5.43 & 2.90 & 3.87 & 2.20 \\
\hline $\mathrm{Li}$ & 4.0 & 3.95 & 3.93 & 0.414 & 0.232 & 0.283 & 0.183 \\
\hline $\mathrm{Mg}$ & 15.9 & 15.9 & 16.4 & 0.133 & 0.037 & 0.065 & 0.021 \\
\hline $\mathrm{Na}$ & 3991 & 3991 & 4159 & 573 & 305 & 368 & 233 \\
\hline $\mathrm{P}$ & 1.46 & 1.46 & 1.03 & 0.091 & 0.011 & 0.013 & 0.000 \\
\hline $\mathrm{S}$ & 5.52 & 5.52 & 4.48 & 0.040 & 0.004 & 0.015 & 0.000 \\
\hline $\mathrm{Si}$ & 21.2 & 21.2 & 10.0 & 0.759 & 0.728 & 1.11 & 0.466 \\
\hline $\mathrm{Sr}$ & 29.0 & 29.0 & 16.2 & 0.119 & 0.033 & 0.053 & 0.019 \\
\hline $\mathrm{Cl}$ & 8224 & 8224 & 7965 & 979 & 540 & 671 & 438 \\
\hline $\mathrm{Br}$ & 61.2 & 61.2 & 58.6 & 10.1 & 5.73 & 6.75 & 4.78 \\
\hline Sum Cations & 8285 & 8285 & 8023 & 989 & 545 & 677 & 442 \\
\hline Sum Anions & 4330 & 4330 & 4308 & 590 & 317 & 381 & 242 \\
\hline TDS & 12615 & 12615 & 12331 & 1580 & 863 & 1059 & 685 \\
\hline$\%$ TDS Removal & $\mathrm{N} / \mathrm{A}$ & $0.0 \%$ & $2.3 \%$ & $87.0 \%$ & $93.0 \%$ & $91.1 \%$ & $94.3 \%$ \\
\hline
\end{tabular}

* Below detection limits (BDL, $<3 \mathrm{mg} / \mathrm{L})$ 


\section{Pretreatment}

NF Permeate

** Slight discrepancies between the BAF effluent and UF permeate in the table may exist from UF and

$\mathrm{NF}$ feed values in the text due to transfer and storage of water in systems

\subsection{DJ basin produced water treatment}

\subsection{1. $B A F$}

After continuous-mode treatment of Piceance basin PW, System A was similarly operated with raw PW from the DJ basin, which contains higher salinity (14.6 g/L TDS) and higher organic matter (385 mg/L DOC). To compensate for these variations, system HRT was increased to $48 \mathrm{hrs}$, providing a $7.4 \mathrm{hr}$ column HRT. DOC and DO concentrations as a function of time in the effluent of the columns in System A are shown in Fig. 6. DOC concentration in the columns' effluent was lower at the beginning due to dilution of the raw PW (dosed) with partially treated feed water. The system reached steady state after $150 \mathrm{hrs}$ with an average effluent DOC concentration below $51 \mathrm{mg} / \mathrm{L}$ (87\% removal). Similar to results from experiments with the Piceance basin PW, DO concentration stabilized with DOC removal. While the system took longer to stabilize with the DJ basin PW than with the Piceance basin PW, approximately 335 $\mathrm{mg} / \mathrm{L}$ DOC was continuously degraded, versus $24 \mathrm{mg} / \mathrm{L}$ DOC in the Piceance basin PW experiment. This demonstrates flexibility of the BAF system to effectively treat PW having higher organic content, maintaining suitable effluent quality for ensuing membrane treatment.

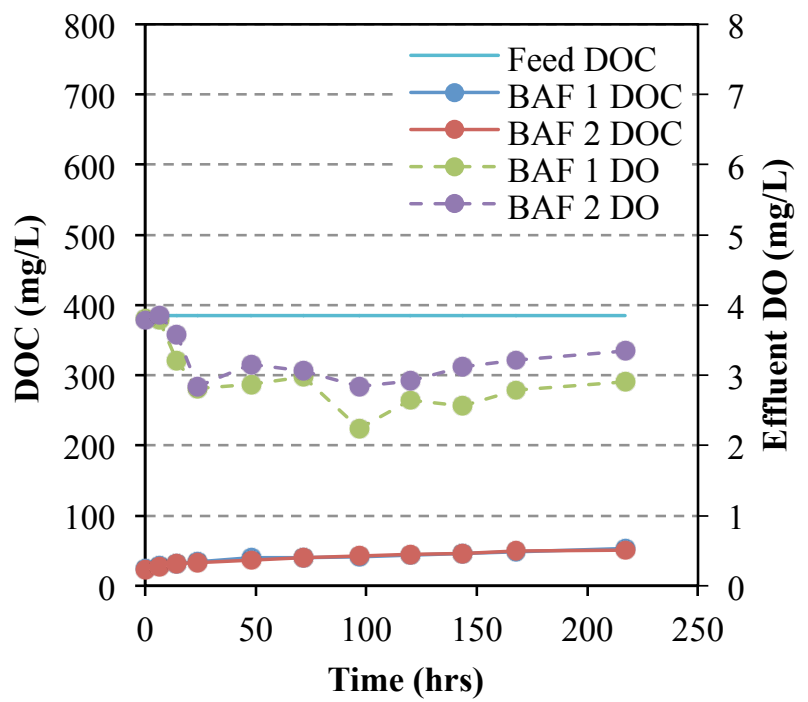

Fig. 6. DOC and DO concentrations as a function of time for continuous-mode DJ basin PW experiments (14.6 g/L TDS) in System A. DOC concentrations of BAF 1 and BAF 2 effluents are identical. The columns were operated in parallel under the following conditions: $7.4 \mathrm{hr}$ 
column HRT, $48 \mathrm{hr}$ system HRT, ambient temperature of $\sim 22{ }^{\circ} \mathrm{C}$, and $2.4 \mathrm{~m} / \mathrm{hr}\left(1.0 \mathrm{gpm} / \mathrm{ft}^{2}\right)$ HLR.

\subsection{2. $U F$}

Capillary UF membranes were used to remove particulate matter and macromolecules in BAF-treated DJ basin PW and further evaluate the effectiveness of BAF pretreatment. The feed consisted of $31.6 \mathrm{mg} / \mathrm{L} \mathrm{DOC}, 14.6 \mathrm{~g} / \mathrm{L}$ TDS, and $2 \mathrm{NTU}$ turbidity. In the first experiment, a PVDF1 membrane operated at $26 \mathrm{LMH}$ recovered $90 \%$ of a $10 \mathrm{~L}$ feed. Membrane backwashing was performed every $5 \mathrm{~min}$ for $36 \mathrm{sec}$ at $150 \mathrm{LMH}$. Permeability and TMP as a function of time are shown in Fig. 7a. The permeability of PVDF1 decreased steadily from $1.88 \mathrm{LMH} / \mathrm{kPa}$ to 1.45 $\mathrm{LMH} / \mathrm{kPa}$, while the TMP slowly increased. Similar to experiments with Piceance basin PW, the permeate turbidity was only 0.2 NTU.

The second experiment with a PVDF2 membrane and a $10 \mathrm{~L}$ feed batch was operated at 38 LMH until $90 \%$ of the feed volume was recovered. Similar to the treatment of Piceance basin PW, backwashing was performed every 5 minutes for 36 seconds at $80 \mathrm{LMH}$. Permeability and TMP as a function of time for experiments with the PVDF2 membrane are shown in Fig. 7b. The initial permeability of the PVDF2 membrane was nearly 3 times higher than that of PVDF1, contributing to the lower operating pressure. Permeability was maintained above $4.35 \mathrm{LMH} / \mathrm{kPa}$ and TMP was maintained below $10.4 \mathrm{kPa}$ (1.5 psi) for the duration of the experiment, producing permeate with an average turbidity of 0.12 NTU. While the DJ basin PW was a more challenging stream than the Piceance basin PW (higher organic content), UF proved to be just as sustainable. 

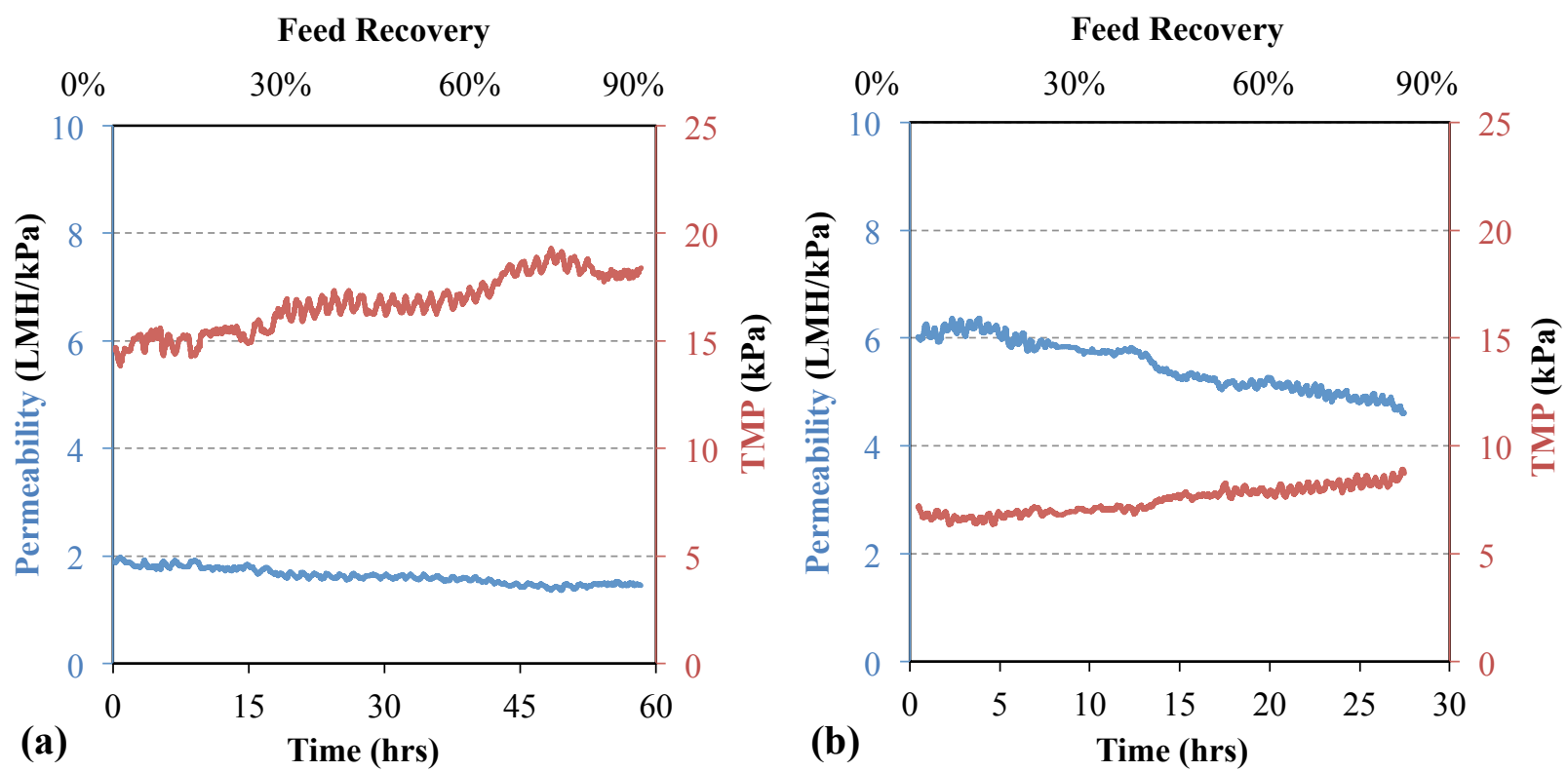

Fig. 7. Permeability and TMP as a function of time for the UF membranes filtering BAF-treated DJ basin PW (14.6 g/L TDS, $31.6 \mathrm{mg} / \mathrm{L}$ DOC, $8.7 \mathrm{mg} / \mathrm{L}$ TN, and 2.0 NTU turbidity) using a (a) PVDF1 module at $26 \mathrm{LMH}$ and (b) PVDF2 module at $38 \mathrm{LMH}$. Each membrane was tested with a $10 \mathrm{~L}$ batch, backwashing every $5 \mathrm{~min}$ for $36 \mathrm{sec}$ at $150 \mathrm{LMH}$ (PVDF1) or at $80 \mathrm{LMH}$ (PVDF2).

\subsubsection{NF}

UF-treated DJ basin PW was collected for desalination by NF, which was conducted similarly to NF tests with pretreated Piceance basin PW. Water flux as a function of time and permeate quality for all pressures tested are shown in Fig. 8. Like results from the Piceance basin PW experiments, tests conducted at lower feed pressures exhibited slower rates of flux decline; the 1035 and $1380 \mathrm{kPa}(150$ and $200 \mathrm{psi})$ tests began at the same initial flux as with the Piceance basin PW, but fouled at slightly higher rates. This can be attributed to a number of factors, especially the feed water quality, because the DJ PW contained higher concentrations of DOC $(31.6 \mathrm{mg} / \mathrm{L})$ and TDS (14.0 g/L). High TDS also tends to cause increased production of EPS and soluble microbial products (SMP) in biological systems, contributing to biofouling of membranes [27, 29]. NF90 membranes are slightly hydrophobic and tend to have a rough surface, which may increase the fouling tendency [80]. This hypothesis is supported by trends observed by Mondal and Wickramasinghe when treating PW of similar DOC concentration [65]. Membrane characterization in their study detected substantial organic fouling on the NF90 surface, in addition to deposits of inorganic species. They noted the membrane hydrophobicity 
and roughness as key factors in membrane fouling. Nonetheless, fouling exhibited similar trends for each pressure, with water flux recoveries up to $100 \%$ after chemical cleaning and comparable flux decline rates after feed replenishment, indicating reversible fouling and stable performance of the membranes.

Rejection of DOC, TN, and TDS was also similar to that of the Piceance basin PW; increased pressure resulted in increased rejection of TN and TDS, while DOC was consistently well rejected in all experiments. TN and TDS was reduced to $1 \mathrm{mg} / \mathrm{L}$ and $885 \mathrm{mg} / \mathrm{L}$ in the $2070 \mathrm{kPa}$ (300 psi) test, respectively, and over $95 \%$ of the DOC was rejected (below $1.6 \mathrm{mg} / \mathrm{L}$ in the $\mathrm{NF}$ permeate) at all pressures. Like the Piceance basin PW experiments, the 1725 and $2070 \mathrm{kPa}$ (250 and $300 \mathrm{psi}$ ) tests had the highest permeate flux and solute rejection, but the lower pressures are more sustainable due to steadier flux decline.
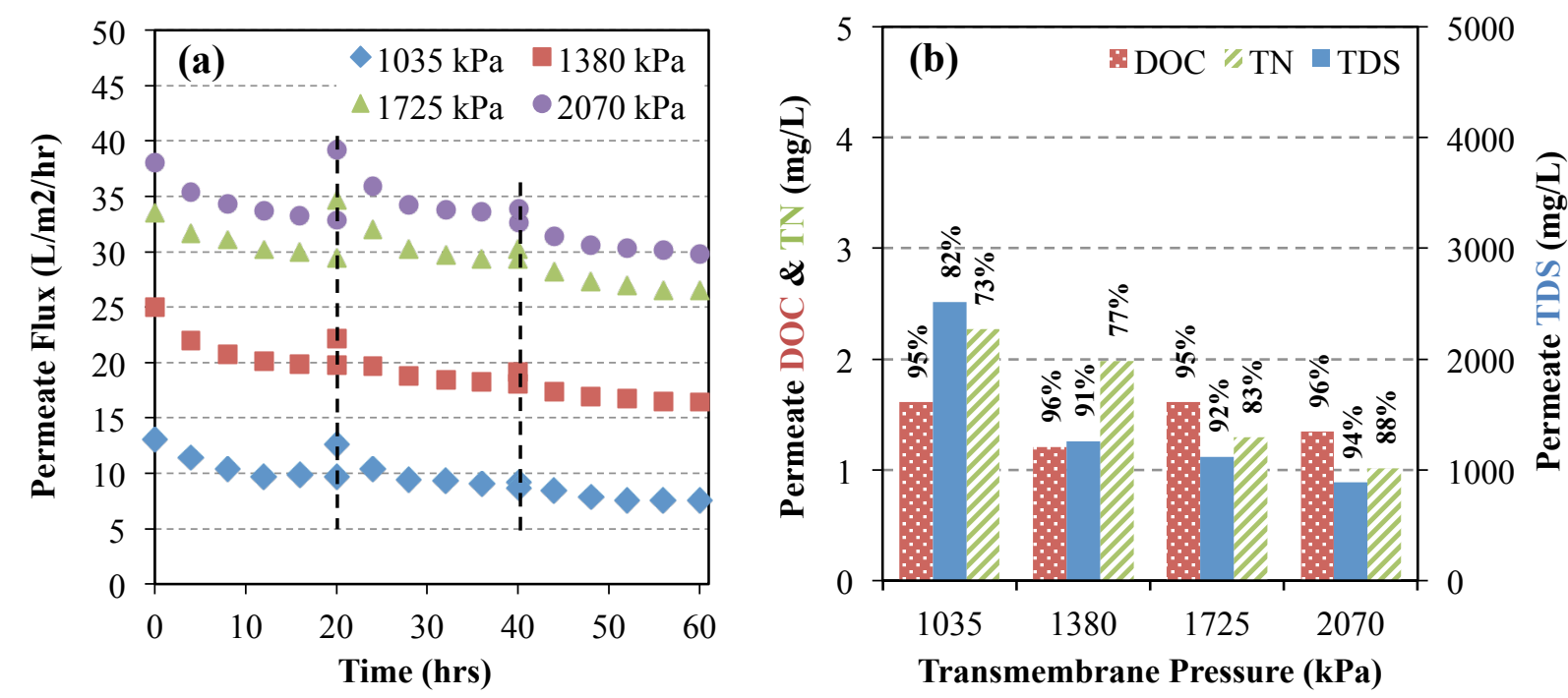

Fig. 8. Results from NF experiments with BAF/UF treated DJ basin PW (14.0 g/L TDS, 31.6 $\mathrm{mg} / \mathrm{L} \mathrm{DOC}, 8.22 \mathrm{mg} / \mathrm{L} \mathrm{TN}$, and $0.45 \mathrm{NTU}$ turbidity). (a) Water flux as a function of time and corresponding (b) permeate concentrations and percent rejection of DOC, TN, and TDS as a function of TMP (1035 $\mathrm{kPa}(150 \mathrm{psi}), 1380 \mathrm{kPa}$ (200 psi), $1725 \mathrm{kPa}(250 \mathrm{psi}), 2070 \mathrm{kPa}$ (300 psi)). Membrane cleanings after $20 \mathrm{hrs}$ and feed replacement after $40 \mathrm{hrs}$ are denoted by dashed lines.

Results from BAF, UF, and NF experiments indicate that the hybrid system was effective at removing organic and inorganic constituents from the DJ basin PW, producing permeate suitable for hydraulic fracturing reuse or potentially stream flow augmentation and irrigation [8]. Removal of organic matter, turbidity, and the main ionic constituents throughout all stages are 
summarized in Table 2. Like the Piceance basin PW, the majority of organic matter was removed during BAF treatment, with additional reductions in turbidity and TN. As expected, UF primarily reduced turbidity and achieved minimal removal of dissolved inorganic contaminants due to the characteristics of UF membranes (large pore size). The combination of BAF and UF is an effective pretreatment for NF, mitigating fouling and enabling desalination of the DJ basin PW stream. In addition to reduction of DOC concentration (less than $1.61 \mathrm{mg} / \mathrm{L}$ ), NF permeate contained only $2.5 \mathrm{~g} / \mathrm{L}$ and $0.9 \mathrm{~g} / \mathrm{L}$ TDS in the 1035 and $2070 \mathrm{kPa}$ (150 and $300 \mathrm{psi}$ ) samples, respectively. This range demonstrates the level of treatment that can be achieved with higher pressures and the flexibility to treat to variable target water qualities for various reuse applications.

Table 2. Heat map summarizing the characteristics of the DJ basin PW after BAF, UF, and NF treatment. Red denotes higher concentrations, while green represents lower concentrations. Color shades are evenly distributed between maximum (dark red) and minimum (dark green) values for each constituent. All units are $\mathrm{mg} / \mathrm{L}$ unless otherwise noted.

\begin{tabular}{|c|c|c|c|cccc|}
\hline & \multicolumn{3}{|c|}{ Pretreatment } & \multicolumn{4}{c|}{ NF Permeate } \\
\hline Analyte & Raw Feed & $\begin{array}{c}\text { BAF effluent } \\
\text { (UF feed)** }\end{array}$ & $\begin{array}{c}\text { UF perm } \\
\text { (NF feed)** }\end{array}$ & $\begin{array}{c}1035 \\
\mathrm{kPa}\end{array}$ & $\begin{array}{c}1380 \\
\mathrm{kPa}\end{array}$ & $\begin{array}{c}1725 \\
\mathrm{kPa}\end{array}$ & $\begin{array}{c}2070 \\
\mathrm{kPa}\end{array}$ \\
\hline Turbidity (NTU) & 19.6 & 1.07 & 0.160 & 0.096 & 0.086 & 0.078 & 0.062 \\
COD & 1157 & 132 & 125 & BDL* & BDL* & BDL* & BDL* \\
DOC & 385 & 40.3 & 31.6 & 1.61 & 1.21 & 1.61 & 1.35 \\
TN & 26.6 & 13.3 & 8.72 & 2.27 & 1.98 & 1.29 & 1.02 \\
B & 9.85 & 9.85 & 7.28 & 6.33 & 5.18 & 4.17 & 3.71 \\
Ba & 2.52 & 2.52 & 4.80 & 0.072 & 0.056 & 0.026 & 0.015 \\
Ca & 43.3 & 43.3 & 41.9 & 0.841 & 0.515 & 0.27 & 0.220 \\
K & 526 & 526 & 520 & 119 & 61.3 & 46.1 & 37.3 \\
Li & 3.95 & 3.95 & 4.10 & 0.586 & 0.299 & 0.248 & 0.196 \\
Mg & 11.5 & 11.5 & 9.55 & 0.155 & 0.104 & 0.045 & 0.024 \\
Na & 4968 & 4968 & 4432 & 776 & 400 & 344 & 271 \\
P & 0.724 & 0.724 & 0.736 & 0.017 & 0.026 & 0.025 & 0.006 \\
S & 10.6 & 10.6 & 5.20 & 0.085 & 0.063 & 0.204 & 0.028 \\
Si & 5.63 & 5.63 & 3.31 & 0.292 & 0.188 & 0.454 & 0.182 \\
Sr & 4.98 & 4.98 & 7.59 & 0.113 & 0.080 & 0.022 & 0.016 \\
Cl & 8919 & 8919 & 8858 & 1595 & 785 & 717 & 568 \\
Br & 62.3 & 62.3 & 55.1 & 13.1 & 6.76 & 6.06 & 4.89 \\
\hline Sum Cations & 5588 & 5588 & 5036 & 903 & 468 & 397 & 312 \\
Sum Anions & 8982 & 8982 & 8913 & 1608 & 792 & 723 & 573 \\
TDS & 14569 & 14569 & 13950 & 2512 & 1260 & 1120 & 885 \\
\hline TDS Removal & N/A & $0.0 \%$ & $4.3 \%$ & $82.0 \%$ & $91.0 \%$ & $92.0 \%$ & $93.7 \%$ \\
\hline
\end{tabular}

* Below detection limits (BDL, $<3 \mathrm{mg} / \mathrm{L})$

** Slight discrepancies between the BAF effluent and UF permeate in the table may exist from UF and NF feed values in the text due to transfer and storage of water in systems

\subsection{DJ basin frac flowback water treatment}




\subsection{1. $B A F$}

Following continuous treatment of DJ basin PW, experiments were repeated using System A under the same operating conditions using DJ basin FFB (48 hr system HRT and $7.4 \mathrm{hr}$ column HRT). This stream contained notably higher concentrations of DOC and TDS, $732 \mathrm{mg} / \mathrm{L}$ and $31.2 \mathrm{~g} / \mathrm{L}$, respectively - twice that of the DJ basin PW. Results in Fig. 9 indicate the continued increase in effluent DOC concentration as the system failed to reach steady state. The continuous increase suggests that the column HRT (7.4 hrs) was not long enough for sufficient biodegradation of DOC in the highly concentrated FFB. Column effluent returned to the feed tank only partially treated, thus increasing the organic content over time and reducing the beneficial effects of dilution observed with the Piceance and DJ basin PW. Additional experiments were conducted with this feed stream to improve the efficacy of BAF treatment. Because long HRTs are not desired in commercial-scale operation, tests with higher GAC volume (biofilters in series) and different aeration rates were investigated.

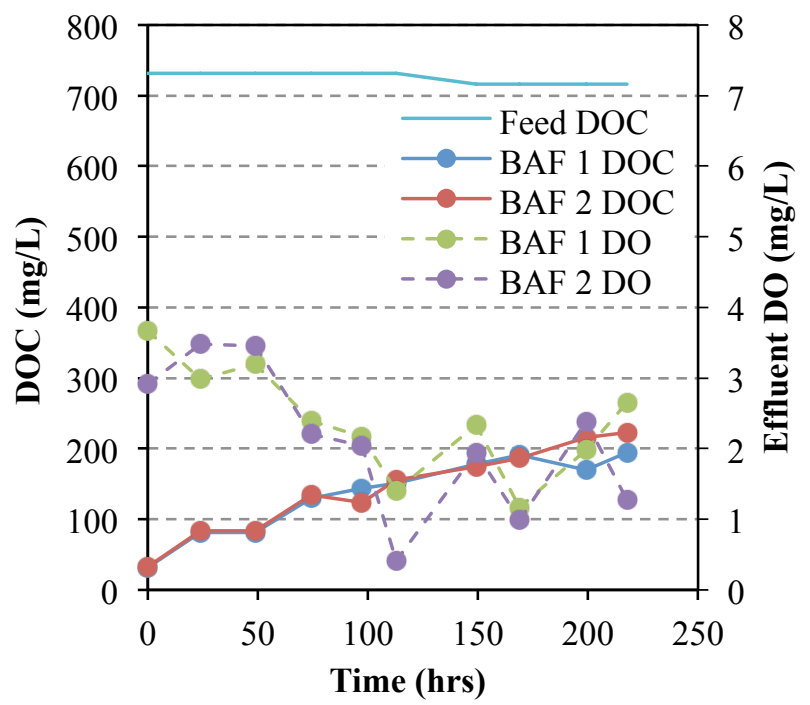

Fig. 9. Effluent DOC and DO concentrations as a function of time for continuous-mode DJ basin FFB experiments conducted on System A. Operating conditions as stated in Fig. 6.

Batch experiments with DJ basin FFB were conducted with System B using 4 filter columns operated in parallel to optimize aeration and DOC removal. BAF 3 was aerated at $0.5 \mathrm{~L} / \mathrm{min}$ in the feed tank, while the other columns received aeration in the column inlet (BAF 4: $0.05 \mathrm{~L} / \mathrm{min}$, BAF 5: $0.1 \mathrm{~L} / \mathrm{min}, \mathrm{BAF}$ 6: $0.25 \mathrm{~L} / \mathrm{min}$ ). DOC concentration as a function of time is shown in Fig. 10 for the four columns of System B. All columns had similar DOC removal rates during the 
first 5 hours while adsorption was the dominant mechanism; however, they became slightly distinguishable as the adsorption sites were exhausted and biodegradation was prevalent, a trend observed in other studies $[40,47,75]$. BAF 4 and BAF 5 had the highest DOC removal rates, suggesting that column aeration is most efficient if provided at low to moderate rates $(0.05-0.1$ LPM). High aeration rates can create an adverse environment due to the turbulence and shear stress on the GAC bed, leading to biomass destruction and detachment. These disturbances are similar to those reported during backwashing, another mechanism used to control biomass growth [81-83]. The optimum aeration condition (0.05 LPM) was applied to the new configuration with columns connected in series to increase the column HRT.

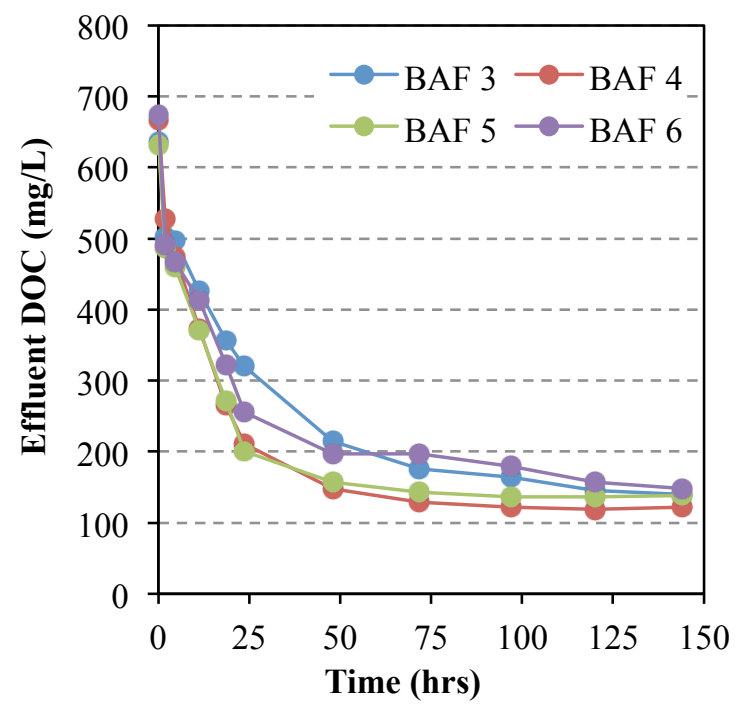

Fig. 10. DOC concentration as a function of time for batch-mode DJ basin FFB experiments using System B with four columns operated in parallel. Aeration for each column was varied at the feed tank (BAF 3: $0.5 \mathrm{~L} / \mathrm{min}$ ) or column inlet (BAF 4: 0.05, BAF 5: 0.1 LPM, BAF 6: 0.25 $\mathrm{L} / \mathrm{min})$.

Continuous-mode experiments with DJ basin FFB were repeated with the four columns of System B connected in series, increasing the column HRT to $20 \mathrm{hrs}$ and maintaining a $48 \mathrm{hr}$ system HRT. BAF 3 and BAF 5 were aerated at $0.05 \mathrm{~L} / \mathrm{min}$. System effluent (column BAF 6) DOC and DO concentrations as a function of time are shown in Fig. 11. The system stabilized after $72 \mathrm{hrs}$ of operation with an effluent DOC concentration below $112 \mathrm{mg} / \mathrm{L}$, resulting in $79 \%$ removal with the new configuration and matching removal achieved during the previous batchmode aeration experiments (Fig. 10). Effluent DO concentration was maintained at $\sim 4 \mathrm{mg} / \mathrm{L}$, 
suggesting sufficient aeration was applied to the BAF system to support biodegradation. The results with DJ basin FFB confirm that BAF can effectively remove high concentrations of organic matter under saline conditions, provided a sufficient HRT.

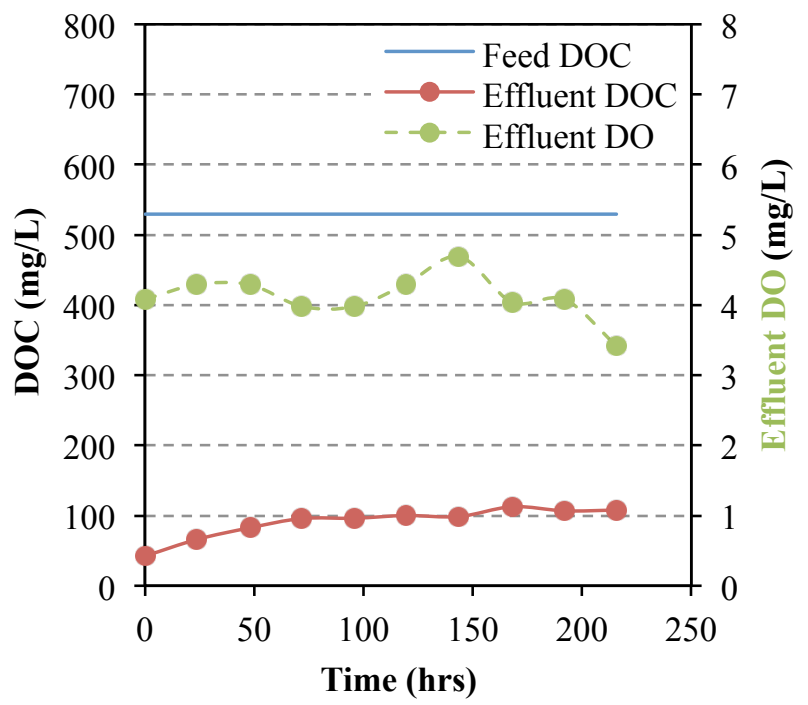

Fig. 11. System effluent DOC and DO concentrations as a function of time for continuous-mode operation of System B with DJ basin FFB. Operation of System B with filter columns connected in series provided a $20 \mathrm{hr}$ column HRT and $48 \mathrm{hr}$ system HRT.

\subsection{2. $U F$}

Following BAF treatment, DJ basin FFB was treated with UF. The FFB feed contained noticeably higher concentrations of DOC $(57 \mathrm{mg} / \mathrm{L}$ DOC) and TDS $(31.2 \mathrm{~g} / \mathrm{L})$, and had higher turbidity (2.8 NTU) than the DJ basin PW. Nonetheless, operating conditions for PVDF1 and PVDF2 remained the same as in the Piceance and DJ basin PW experiments (26 and 38 LMH, respectively). Membrane permeability and TMP as a function of time for each UF membrane is shown in Fig. 12. Results indicate comparable trends to that of the DJ basin PW, despite the high concentrations of organic and inorganic constituents. The permeability of PVDF1 slowly declined and the TMP remained near $13.8 \mathrm{kPa}$ (2 psi) throughout the experiment. PVDF2 experienced no loss of permeability, with TMP remaining constant, demonstrating the effectiveness of BAF pretreatment and the UF process. These results are even more substantial when considering the water quality of the FFB feed. In relation to the high salinity, Fakhru'lRazi et al. and Reid et al. observed increased biological products (e.g., SMP and EPS) with increasing concentrations of TDS during biological treatment of PW and municipal water [25, 
29]. These microbial products have been well documented in the literature, most often in MBRs, as critical membrane foulants [27, 84]. Despite the challenging feed water and high fouling potential, permeate turbidity was reduced to 0.2 NTU by PVDF1 and 0.15 NTU by PVDF2, serving as sufficient pretreatment for NF.
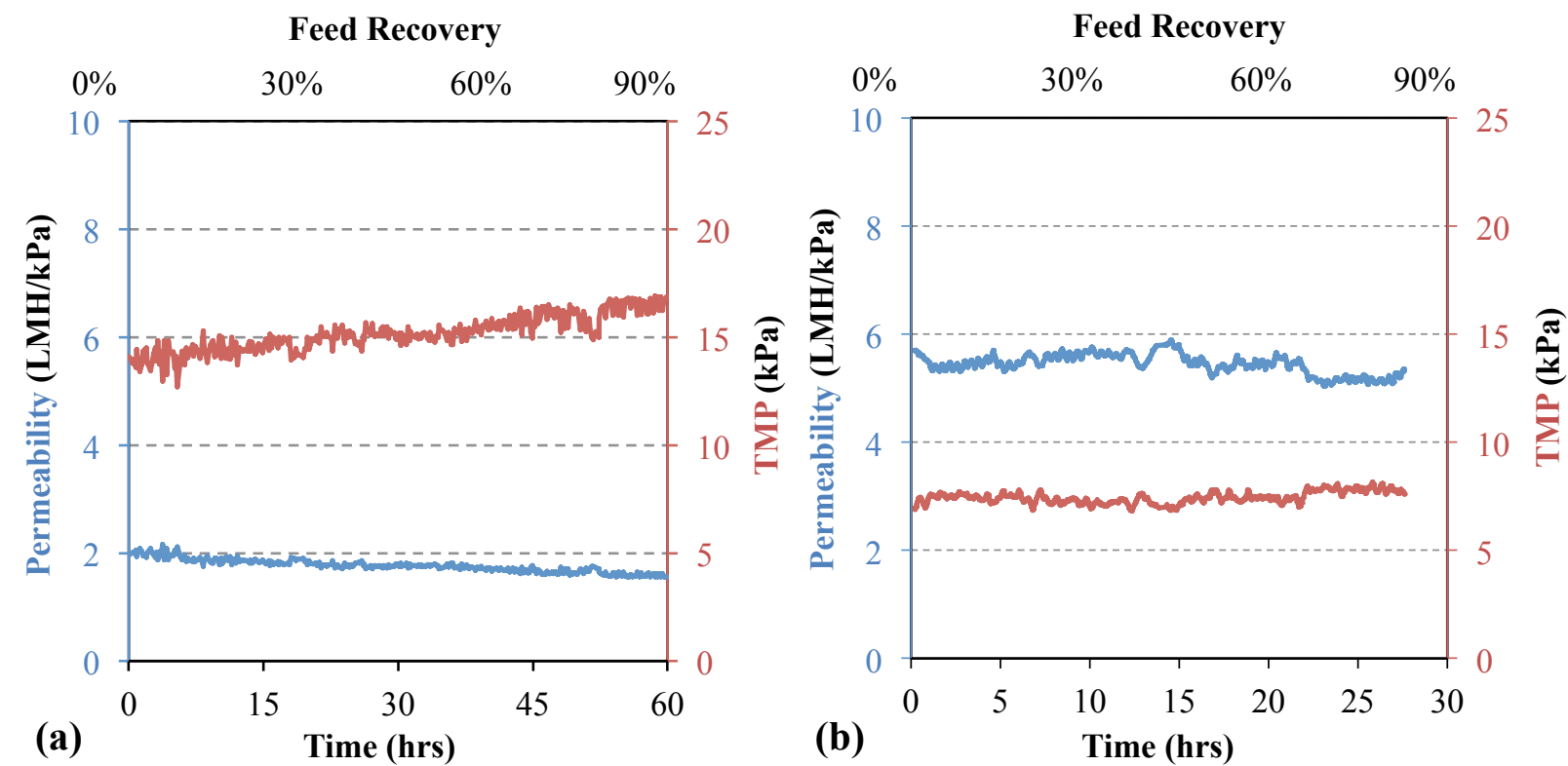

Fig. 12. UF permeability and TMP as a function of time during experiments conducted with BAF-treated DJ basin FFB (31.2 g/L TDS, $57.2 \mathrm{mg} / \mathrm{L} \mathrm{DOC,} 27.7 \mathrm{mg} / \mathrm{L}$ TN, and $2.8 \mathrm{NTU}$ turbidity) using (a) PVDF1 operated at $26 \mathrm{LMH}$ and (b) PVDF2 operated at $38 \mathrm{LMH}$. Each membrane, operated at critical flux, treated a $10 \mathrm{~L}$ batch until reaching $90 \%$ recovery. Backwashing was performed every 5 min for $36 \mathrm{sec}$ at $150 \mathrm{LMH}$ for PVDF1 and at $80 \mathrm{LMH}$ for PVDF2.

\subsection{3. $N F$}

After BAF and UF treatment of DJ basin FFB, UF permeate was further treated by NF. Experiments were conducted under the same conditions as in previous tests with Piceance PW and DJ PW. However, due to the high salinity and thus higher osmotic pressure of the FFB (29.6 $\mathrm{g} / \mathrm{L}$ ), the $1035 \mathrm{kPa}$ (150 psi) test was excluded due to low permeate flux. Water flux as a function of time and permeate quality for all other pressures are shown in Fig. 13. Tests at lower pressures, such as the 1380 and $1725 \mathrm{kPa}$ (200 and $250 \mathrm{psi}$ ) tests, demonstrated lower rates of fouling and flux decline, but also exhibited lower rejection than the $2070 \mathrm{kPa}(300 \mathrm{psi})$ test. After the first $20 \mathrm{hrs}$ of testing, flux was recovered (most noticeably with the $2070 \mathrm{kPa}$ test) with chemical cleaning, before resuming similar flux decline trends. The replacement of feed batches at $40 \mathrm{hrs}$, introducing new foulants to the system, resulted in slight flux decline during the first 5 
hrs at each pressure, followed by flux stabilization. During investigation of membrane fouling with wastewater reclamation, $\mathrm{Xu}$ and Drewes also noted severe declines in initial flux, attributed to adsorption of hydrophobic organic matter [60]. Smoother and more hydrophilic membranes in their study did not exhibit these trends, suggesting that use of such membranes with PW and FFB may mitigate fouling.

Although this water had substantially higher fouling potential than PW, most notably with the higher TDS $(29.6 \mathrm{~g} / \mathrm{L})$ and TOC $(56.1 \mathrm{mg} / \mathrm{L})$, high quality permeate suitable for reuse in hydraulic fracturing was produced. Approximately 98\% DOC was rejected at each pressure, reducing it to $1.5 \mathrm{mg} / \mathrm{L}$, while $\mathrm{TN}$ was increasingly removed with pressure to below $4.4 \mathrm{mg} / \mathrm{L}$ at $1380 \mathrm{kPa}$ (200 psi). Like in the PW experiments, rejection of TDS also increased with pressure from $67 \%(9.7 \mathrm{~g} / \mathrm{L})$ at $1380 \mathrm{kPa}$ to $91 \%(2.8 \mathrm{~g} / \mathrm{L})$ at $2070 \mathrm{kPa}(300 \mathrm{psi})$. A second pass $\mathrm{NF}$ treatment of the NF permeate can potentially produce water having close to drinking water quality, as demonstrated in previous studies with multiple passes [85].
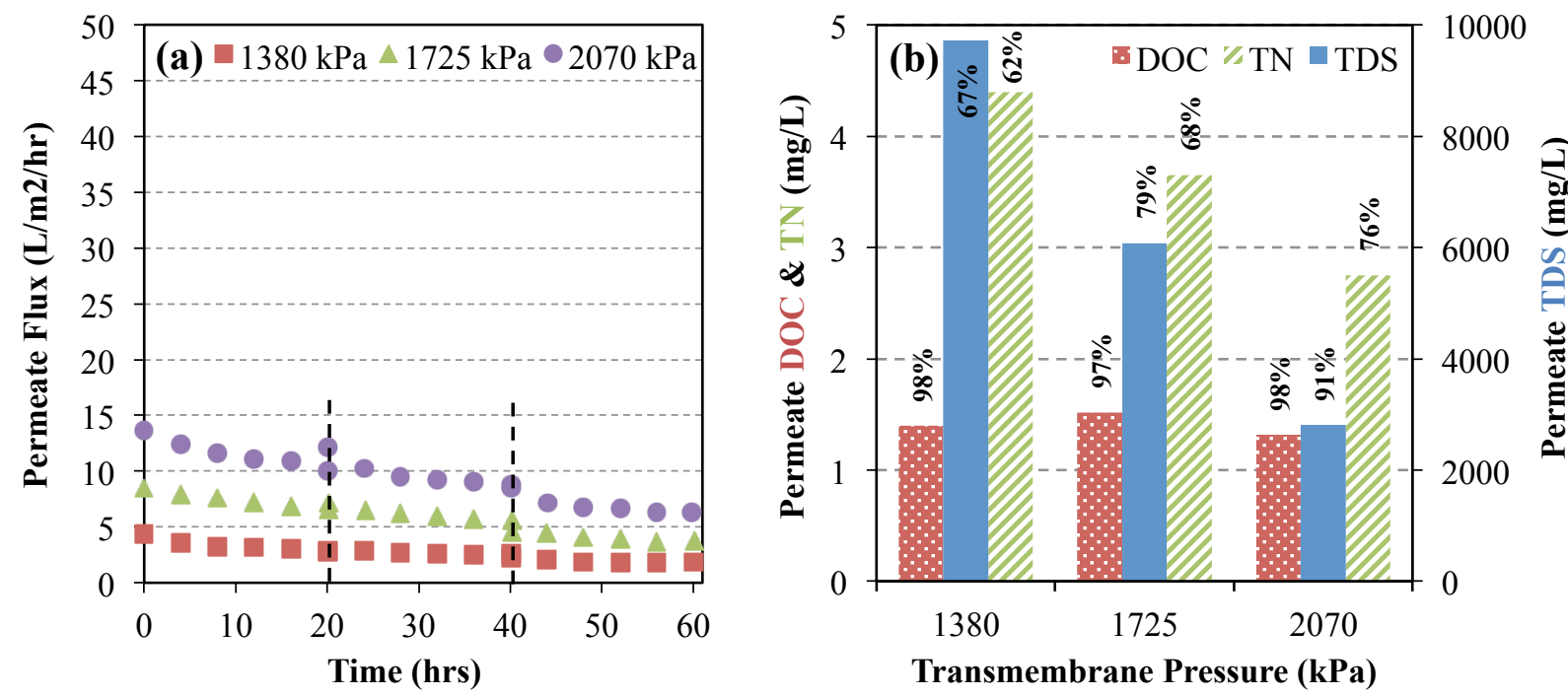

Fig. 13. NF experiments with BAF/UF treated DJ basin FFB (29.6 g/L TDS, $56.1 \mathrm{mg} / \mathrm{L}$ DOC, $11.6 \mathrm{mg} / \mathrm{L} \mathrm{TN}, 0.59 \mathrm{NTU}$ turbidity). (a) Water flux as a function of time and corresponding (b) permeate concentrations and percent rejection of DOC, TN, and TDS as a function of TMP (1035 kPa (150 psi), $1380 \mathrm{kPa}(200 \mathrm{psi}), 1725 \mathrm{kPa}$ (250 psi), $2070 \mathrm{kPa}(300 \mathrm{psi}))$. Membrane cleaning after $20 \mathrm{hrs}$ and feed replacement after $40 \mathrm{hrs}$ is denoted by dashed lines.

The main organic and inorganic constituents present in the DJ basin FFB and after each treatment stage are summarized in Table 3. Results indicate that the hybrid system was effective at removing organic and inorganic contaminants from the DJ FFB, producing permeate suitable for hydraulic fracturing reuse. Trends follow those observed in the Piceance PW and DJ PW 
experiments; the majority of organic matter (and some turbidity) was removed by BAF, while UF mainly removed turbidity and NF rejected both organic and inorganic compounds. Comprehensively, from raw FFB to NF permeate, up to $99.9 \%$ of turbidity, $99.8 \%$ of DOC, and $91.0 \%$ of TDS were removed. This confirms the ability of the biological and membrane treatment scheme to treat challenging O\&G waste streams.

Table 3. Heat map summarizing the characteristics of the DJ basin FFB after BAF, UF, and NF treatment. Red denotes higher concentrations, while green represents lower concentrations. Color shades are evenly distributed between maximum (dark red) and minimum (dark green) values for each constituent. All units are $\mathrm{mg} / \mathrm{L}$ unless otherwise noted.

\begin{tabular}{|c|c|c|c|ccc|}
\hline & \multicolumn{3}{|c|}{ Pretreatment } & \multicolumn{3}{c|}{ NF } \\
\hline \multirow{2}{*}{ Analyte } & $\begin{array}{c}\text { Raw } \\
\text { Feed }\end{array}$ & $\begin{array}{c}\text { BAF eff } \\
\text { (UF feed)* }\end{array}$ & $\begin{array}{c}\text { UF perm } \\
\text { (NF feed) }\end{array}$ & $\begin{array}{c}1380 \\
\mathrm{kPa}\end{array}$ & $\begin{array}{c}1725 \\
\mathrm{kPa}\end{array}$ & $\begin{array}{c}2070 \\
\mathrm{kPa}\end{array}$ \\
\hline Turbidity (NTU) & 56.4 & 24 & 0.175 & 0.12 & 0.061 & 0.056 \\
COD & 2872 & 277 & 235 & 48.2 & 41.7 & 13.5 \\
DOC & 732 & 57.2 & 56.1 & 1.40 & 1.52 & 1.32 \\
TN & 36.7 & 27.7 & 11.6 & 4.39 & 3.65 & 2.75 \\
\cline { 2 - 7 } $\mathrm{B}$ & 22.8 & 22.8 & 18.4 & 16.5 & 15.8 & 13.3 \\
$\mathrm{Ba}$ & 25.6 & 25.6 & 20.0 & 0.364 & 0.209 & 0.139 \\
$\mathrm{Ca}$ & 546 & 546 & 373 & 7.20 & 4.08 & 2.40 \\
$\mathrm{~K}$ & 49.7 & 49.7 & 40.8 & 17.4 & 11.6 & 6.14 \\
$\mathrm{Li}$ & 7.88 & 7.88 & 6.31 & 1.76 & 1.08 & 0.484 \\
$\mathrm{Mg}$ & 70.5 & 70.5 & 67.8 & 0.981 & 0.651 & 0.386 \\
$\mathrm{Na}$ & 9921 & 9921 & 8838 & 3039 & 1921 & 900 \\
$\mathrm{P}$ & 0.134 & 0.134 & 0.119 & 0.040 & 0.031 & 0.005 \\
$\mathrm{~S}$ & 9.48 & 9.48 & 9.01 & 0.035 & 0.000 & 0.140 \\
$\mathrm{Si}$ & 25.7 & 25.7 & 11.5 & 2.31 & 1.53 & 0.61 \\
$\mathrm{Sr}$ & 72.5 & 72.5 & 57.6 & 0.884 & 0.571 & 0.347 \\
$\mathrm{Cl}$ & 20215 & 20215 & 20011 & 6561 & 4049 & 1866 \\
$\mathrm{Br}$ & 227 & 227 & 164 & 74.9 & 74.9 & 23.1 \\
\hline Cations & 10751 & 10751 & 9443 & 3086 & 1956 & 923 \\
$\mathrm{Anions}$ & 20442 & 20442 & 20175 & 6636 & 4124 & 1889 \\
$\mathrm{TDS}$ & 31193 & 31193 & 29618 & 9722 & 6080 & 2813 \\
\hline \%DS Removal & N/A & $0 \%$ & $5 \%$ & $67 \%$ & $79 \%$ & $91 \%$ \\
\hline
\end{tabular}

* Slight discrepancies between the BAF effluent and UF permeate in the table may exist from UF and NF feed values in the text due to transfer and storage of water in systems

\subsubsection{D fluorescence}

To further understand and characterize the dissolved organic matter fractions throughout treatment, 3D EEM fluorescence tests with DJ basin FFB were performed in the BAF feed and effluent and NF permeate samples. Generated EEMs were classified into five zones that correspond to different fractions of dissolved organic matter. The zones, numbered from I to V, have been referred to in the literature to be associated with compounds such as simple aromatic 
proteins (I and II), fulvic acids (III), SMPs (IV), and humic acid-like organics (V) [86-88]. Fluorescence intensity (normalized to RU) in EEMs generated from FFB samples is presented in Fig. 14. The EEM spectra from raw FFB (Fig. 14a) displays two primary peaks in the II and IV regions, associated with aromatic proteins and microbial-like byproducts [86, 88]. After BAF treatment (Fig. 14b), maximum fluorescence intensity was reduced from 340 to 20 RU, indicating substantial removal in the II and IV regions. A higher fraction of dissolved organic matter was displayed in region IV, while region II fluoresced with noticeably less intensity, suggesting the degradation of proteins into lower molecular weight compounds and production of new byproducts from microbial activity. High fluorescence protein peaks were detected in studies examining other O\&G wastewaters from the Niobrara formation, likely due to the biogenic formation of oil and gas at these locations [86, 89]. EEM spectra from samples after NF treatment display peaks of lower fluorescence intensity $(<0.3 \mathrm{RU})$ in the same regions, corresponding to DOC results that demonstrate increased organic matter removal with pressure. The humic-like organic peak displayed in Fig. 14c (NF at $1380 \mathrm{kPa}$ (200 psi)) was likely present in previous samples, but was not visible due to the EEM scale used. More quantitative methods such as parallel factor analysis (PARAFAC) are required for further investigation [73]. Nevertheless, NF at $2070 \mathrm{kPa}$ (300 psi) (Fig. 14d) exhibits higher removal of dissolved organic matter in all regions than at $1380 \mathrm{kPa}$ (200 psi). These results elucidate trends observed throughout BAF, UF, and NF treatment - the bulk of organic matter is degraded by biological treatment, with increased removal of recalcitrant dissolved organic matter with membrane filtration.
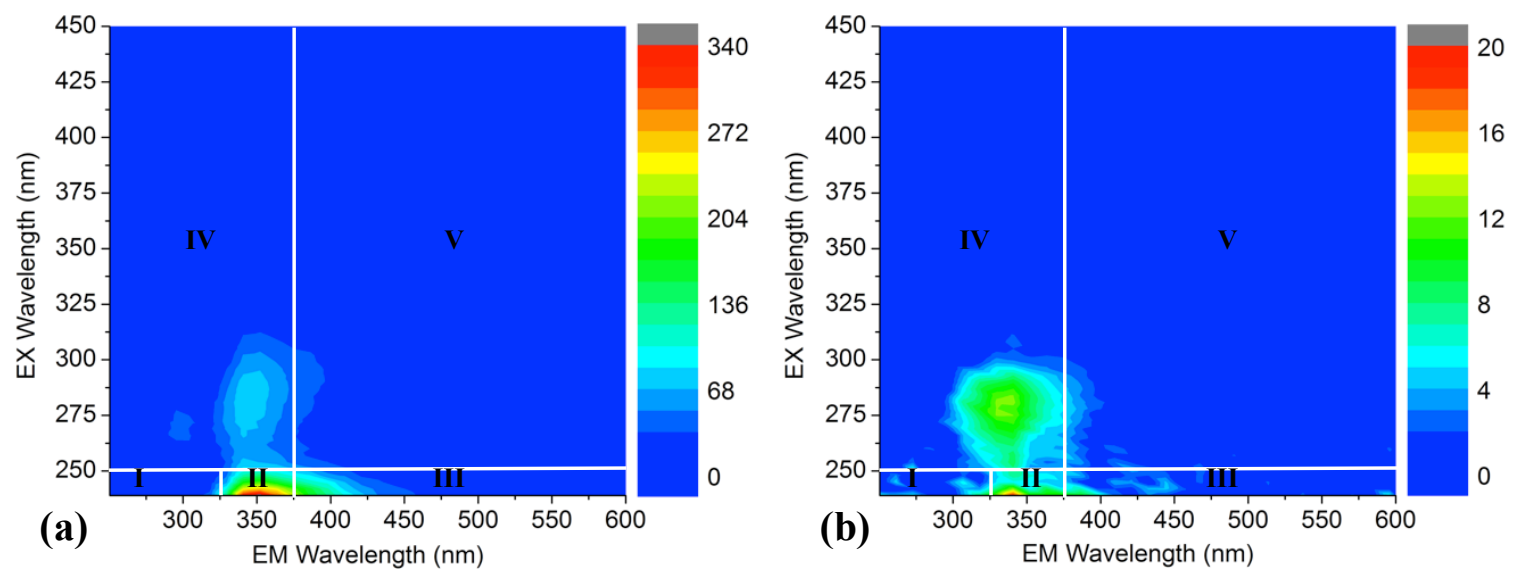

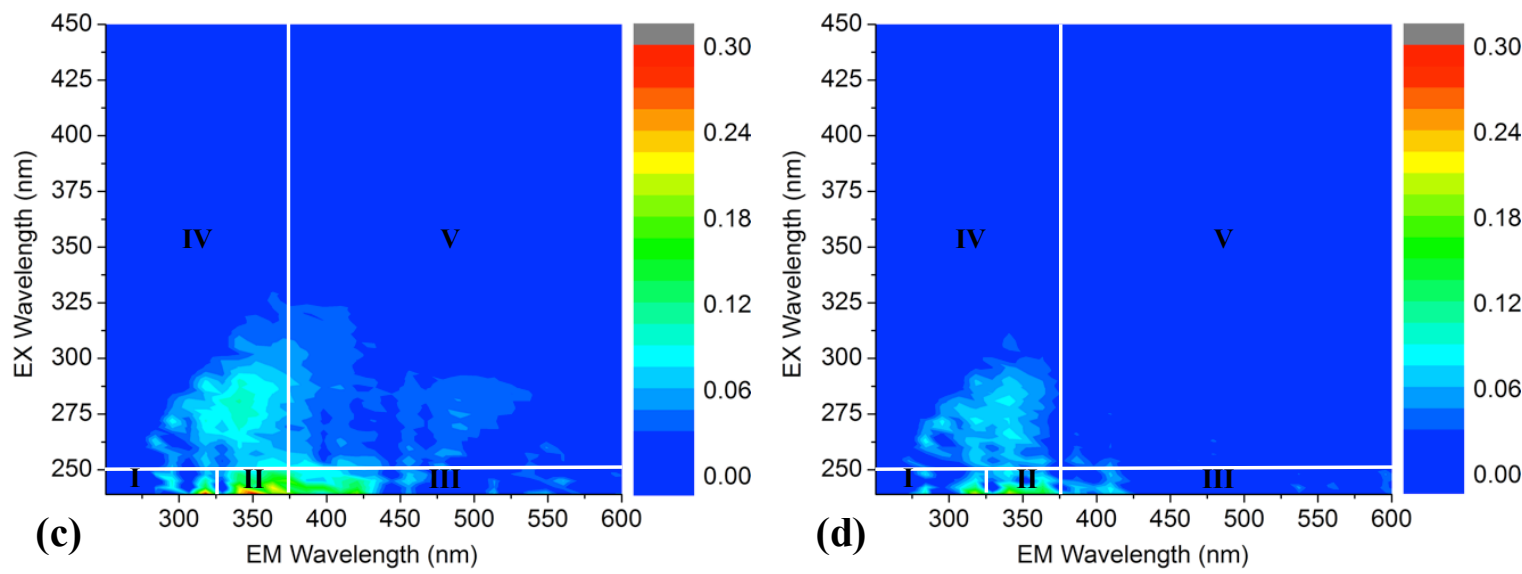

Fig. 14. 3D EEMs of DJ basin FFB throughout treatment, classifying dissolved organic matter in (a) raw DJ FFB and after (b) BAF, (c) NF at $1380 \mathrm{kPa}$ (200 psi), and (d) NF at $2070 \mathrm{kPa}$ (300 psi). EEMs are categorized into 5 zones: (I and II) simple aromatic proteins, (III) fulvic acids, (IV) soluble microbial products, and (V) humic acid-like organics. Fluorescence intensity is normalized to Raman Units.

\section{Conclusion}

A hybrid system coupling BAF, UF, and NF was investigated for the treatment of three highly variable O\&G waste streams-Piceance and DJ basin PW and DJ basin FFB. The BAF system proved effective in removing organic matter from the three waste streams, despite the variable feed chemistry and salinity (ranging from 12.6 to $31.2 \mathrm{~g} / \mathrm{L}$ TDS). After microbial acclimation during start-up, no additional acclimation or transitional periods were required between feed streams. This suggests that BAF, especially when limited to similar basins or a single producing formation, is a robust and versatile treatment technology that can withstand varying feed compositions. Following BAF, UF treatment was most effective in reducing the turbidity and further preparing the water for NF treatment. The PVDF1 and PVDF2 membranes performed similarly in turbidity removal (0.1- 0.2 NTU permeate) and demonstrated minimal fouling. However, the PVDF2 membranes exhibited significantly higher water flux and permeability, and lower TMP, ultimately displaying more favorable characteristics. This demonstrates the importance of membrane comparison and warrants addition research, including optimization of operating conditions (e.g., cross-flow velocity, backwash intensity and frequency, cleaning agents). NF was especially effective in the desalination of the BAF/UF treated waste streams. TDS was reduced to as low as $\sim 700 \mathrm{mg} / \mathrm{L}$ (Piceance PW, $2070 \mathrm{kPa}$ ), verifying that with sufficient pretreatment and multiple treatment barriers, PW and FFB can be treated for potential reuse applications, including livestock watering, stream flow augmentation, 
aquifer recharge, hydraulic fracturing, and other industrial uses. Treatment schemes like this may be pursued in the near future for decentralized systems that enable reclamation and reuse of O\&G wastewaters.

\section{Acknowledgements}

The authors would like to thank the National Science Foundation Sustainability Research Network program under Cooperative Agreement CBET-1240584 for supporting this study. The authors would also like to thank Aurora Water for providing GAC media, Koch Membrane Systems and Dow Chemicals for providing membranes, and Mr. Daniel Freedman, Dr. Ryan Holloway, Dr. Bryan Coday, Mr. Tani Cath, Mr. Mike Veres, and Ms. Estefani Bustos for their scientific and technical support.

\section{References}

[1] U.S.E.I. Administration, Annual energy outlook 2015 with projections to 2040, 2015, Washington, DC.

[2] B.G. Rahm, S.J. Riha, Toward strategic management of shale gas development: Regional, collective impacts on water resources, Environ. Sci. Policy 17 (2012) 12-23.

[3] E.B. Casey, R. Tisdale, C. Jackson, Water for U.S. hydraulic fracturing: Competitive strategies, solutions and outlook, 2014-2020, 2014, Bluefield Research, Boston, MA. http://bluefieldresearch.com/water-for-fracking-2014

[4] P. Boschee, Produced and flowback water recycling and reuse: Economics, limitations, and technology, Oil and Gas Facilities 3 (2014) 16-21.

[5] G.W.P. Council, Modern shale gas development in the United States: A primer, US Department of Energy, Office of Fossil Energy, 2009.

[6] B. Bai, S. Goodwin, K. Carlson, Modeling of frac flowback and produced water volume from Wattenberg oil and gas field, J. Petrol. Sci. Eng. 108 (2013) 383-392.

[7] Y. Lester, I. Ferrer, E.M. Thurman, K.A. Sitterley, J.A. Korak, G. Aiken, K.G. Linden, Characterization of hydraulic fracturing flowback water in Colorado: Implications for water treatment, Sci. Total Environ. 512-513 (2015) 637-644.

[8] K. Guerra, K. Dahm, S. Dundorf, Oil and gas produced water management and beneficial use in the Western United States, US Department of the Interior, Bureau of Reclamation, 2011. 
[9] C. Clark, J. Veil, Produced water volumes and management practices in the United States, Argonne National Laboratory, 2009.

[10] K.B. Gregory, R.D. Vidic, D.A. Dzombak, Water management challenges associated with the production of shale gas by hydraulic fracturing, Elements 7 (2011) 181-186.

[11] A. Fakhru'l-Razi, A. Pendashteh, L.C. Abdullah, D.R.A. Biak, S.S. Madaeni, Z.Z. Abidin, Review of technologies for oil and gas produced water treatment, J. Hazard. Mater. 170 (2009) 530-551.

[12] J.A. Veil, M.G. Puder, D. Elcock, R.J. Redweik Jr, A white paper describing produced water from production of crude oil, natural gas, and coal bed methane, Argonne National Laboratory, 2004.

[13] J.M. Lee, T.C. Frankiewicz, Treatment of produced water with an ultrafiltration (UF) membrane-a field trial, SPE Annual Technical Conference and Exhibition, Dallas, TX, October 9-12, 2005.

[14] J.D. Arthur, B.G. Langhus, C. Patel, Technical summary of oil \& gas produced water treatment technologies, ALL Consulting, LLC, 2005.

[15] S. Zhao, G. Huang, G. Cheng, Y. Wang, H. Fu, Hardness, COD and turbidity removals from produced water by electrocoagulation pretreatment prior to reverse osmosis membranes, Desal. 344 (2014) 454-462.

[16] M. Çakmakce, N. Kayaalp, I. Koyuncu, Desalination of produced water from oil production fields by membrane processes, Desalination 222 (2008) 176-186.

[17] K.L. Hickenbottom, N.T. Hancock, N.R. Hutchings, E.W. Appleton, E.G. Beaudry, P. $\mathrm{Xu}, \mathrm{T} . \mathrm{Y}$. Cath, Forward osmosis treatment of drilling mud and fracturing wastewater from oil and gas operations, Desal. 312 (2013) 60-66.

[18] B.D. Coday, N. Almaraz, T.Y. Cath, Forward osmosis desalination of oil and gas wastewater: Impacts of membrane selection and operating conditions on process performance, J. Membr. Sci. 488 (2015) 40-55.

[19] Z. Yang, N. Zhang, Treatment of produced wastewater by flocculation settlement-Fenton oxidation-adsorption method, J. Xi'an Petrol. Inst. 20 (2005) 50-53.

[20] C. Fang, J. Lin, Air stripping for treatment of produced water, J. Pet. Technol. 40 (1988) 619-624.

[21] Metcalf, Eddy, Wastewater engineering: Treatment and resource recovery, 5, McGrawHill, 2014. 
[22] W. Eckenfelder, J. Musterman, Activated sludge: Treatment of industrial wastewater, Technomic Publishing Company, Inc., Lancaster, PA, 1998.

[23] W.W. Eckenfelder, D.L. Ford, A.J. Englande, Industrial water quality, 4, McGraw-Hill Professional, 2008.

[24] A. Janson, M. Katebah, A. Santos, S. Adham, S. Judd, Assessing the biotreatability of produced water from a Qatari gas field, International Petroleum Technology Conference, Doha, Qatar, January 19-22, 2014.

[25] A. Fakhru'l-Razi, A. Pendashteh, Z.Z. Abidin, L.C. Abdullah, D.R.A. Biak, S.S. Madaeni, Application of membrane-coupled sequencing batch reactor for oilfield produced water recycle and beneficial re-use, Bioresour. Technol. 101 (2010) 6942-6949.

[26] O. Lefebvre, R. Moletta, Treatment of organic pollution in industrial saline wastewater: A literature review, Water Res. 40 (2006) 3671-3682.

[27] S. Judd, The MBR book: Principles and applications of membrane bioreactors for water and wastewater treatment, 2, Elsevier, Burlington, MA, 2010.

[28] H.Y. Ng, S.L. Ong, W.J. Ng, Effects of sodium chloride on the performance of a sequencing batch reactor, J. Environ. Eng. 131 (2005) 1557-1564.

[29] E. Reid, X. Liu, S. Judd, Effect of high salinity on activated sludge characteristics and membrane permeability in an immersed membrane bioreactor, J. Membr. Sci. 283 (2006) 164-171.

[30] M. Johir, S. Vigneswaran, J. Kandasamy, R. BenAim, A. Grasmick, Effect of salt concentration on membrane bioreactor (MBR) performances: Detailed organic characterization, Desal. 322 (2013) 13-20.

[31] J.L. Campos, A. Mosquera-Corral, M. Sanchez, R. Méndez, J.M. Lema, Nitrification in saline wastewater with high ammonia concentration in an activated sludge unit, Water Res. 36 (2002) 2555-2560.

[32] A.R. Dinçer, F. Kargi, Salt inhibition kinetics in nitrification of synthetic saline wastewater, Enzyme Microb. Technol. 28 (2001) 661-665.

[33] A.E. Rimer, E.A. Kobylinski, G.L. Hunter, F.A. DiGiano, B. Bierck, Impacts of membrane process residuals on wastewater treatment: A guidance manual, 2008, WateReuse Foundation, Alexandria, VA.

[34] E.A. Sharghi, B. Bonakdarpour, P. Roustazade, M.A. Amoozegar, A.R. Rabbani, The biological treatment of high salinity synthetic oilfield produced water in a submerged membrane bioreactor using a halophilic bacterial consortium, J. Chem. Technol. Biot. 88 (2013) 2016-2026. 
[35] M.R.L. Bonfá, M.J. Grossman, E. Mellado, L.R. Durrant, Biodegradation of aromatic hydrocarbons by Haloarchaea and their use for the reduction of the chemical oxygen demand of hypersaline petroleum produced water, Chemosphere 84 (2011) 1671-1676.

[36] A. Pendashteh, A. Fakhru' 1 - Razi, T. Chuah, A.D. Radiah, S. Madaeni, Z. Zurina, Biological treatment of produced water in a sequencing batch reactor by a consortium of isolated halophilic microorganisms, Environ. Technol. 31 (2010) 1229-1239.

[37] A.R. Pendashteh, L.C. Abdullah, A. Fakhru'l-Razi, S.S. Madaeni, Z. Zainal Abidin, D.R. Awang Biak, Evaluation of membrane bioreactor for hypersaline oily wastewater treatment, Process Saf. Environ. 90 (2012) 45-55.

[38] D.S. Chaudhary, S. Vigneswaran, H.-H. Ngo, W.G. Shim, H. Moon, Biofilter in water and wastewater treatment, Korean J. Chem. Eng. 20 (2003) 1054-1065.

[39] B.E. Rittmann, Aerobic biological treatment. Water treatment processes, Environmental science \& technology 21 (1987) 128-136.

[40] T.T.L. Hoang, H. Shon, D. Chaudhary, S. Vigneswaran, H.H. Ngo, Granular activated carbon (GAC) biofilter for low strength wastewater treatment, Fluid/Part. Sep. J. 16 (2004) 185-191.

[41] J. Hollender, S.G. Zimmermann, S. Koepke, M. Krauss, C.S. McArdell, C. Ort, H. Singer, U. von Gunten, H. Siegrist, Elimination of organic micropollutants in a municipal wastewater treatment plant upgraded with a full-scale post-ozonation followed by sand filtration, Environ. Sci. Technol. 43 (2009) 7862-7869.

[42] J. Reungoat, B.I. Escher, M. Macova, F.X. Argaud, W. Gernjak, J. Keller, Ozonation and biological activated carbon filtration of wastewater treatment plant effluents, Water Res. 46 (2012) 863-872.

[43] G. Lofrano, S. Meriç, G.E. Zengin, D. Orhon, Chemical and biological treatment technologies for leather tannery chemicals and wastewaters: A review, Sci. Total Environ. 461-462 (2013) 265-281.

[44] B. Guieysse, Z.N. Norvill, Sequential chemical-biological processes for the treatment of industrial wastewaters: review of recent progresses and critical assessment, J. Hazard. Mater. 267 (2014) 142-152.

[45] G. O'Toole, H.B. Kaplan, R. Kolter, Biofilm formation as microbial development, Annu. Rev. Microbiol. 54 (2000) 49-79.

[46] J.E. Alleman, T. Prakasam, Reflections on seven decades of activated sludge history, J. Water Pollut. Control Fed. (1983) 436-443. 
[47] W. Xing, H. Ngo, S. Kim, W. Guo, P. Hagare, Adsorption and bioadsorption of granular activated carbon (GAC) for dissolved organic carbon (DOC) removal in wastewater, Bioresour. Technol. 99 (2008) 8674-8678.

[48] Z.K. Chowdhury, Activated carbon: Solutions for improving water quality, American Water Works Association, 2013.

[49] L. Mendoza-Espinosa, T. Stephenson, A review of biological aerated filters (BAFs) for wastewater treatment, Environ. Eng. Sci. 16 (1999) 201-216.

[50] X. Zhao, R.F. Hickey, T.C. Voice, Long-term evaluation of adsorption capacity in a biological activated carbon fluidized bed reactor system, Water Res. 33 (1999) 29832991.

[51] S.W. Maloney, N.R. Adrian, R.F. Hickey, R.L. Heine, Anaerobic treatment of pinkwater in a fluidized bed reactor containing GAC, J. Hazard. Mater. 92 (2002) 77-88.

[52] F. Persson, J. Långmark, G. Heinicke, T. Hedberg, J. Tobiason, T.-A. Stenström, M. Hermansson, Characterisation of the behaviour of particles in biofilters for pre-treatment of drinking water, Water Res. 39 (2005) 3791-3800.

[53] K.-L. Ho, Y.-C. Chung, Y.-H. Lin, C.-P. Tseng, Microbial populations analysis and field application of biofilter for the removal of volatile-sulfur compounds from swine wastewater treatment system, J. Hazard. Mater. 152 (2008) 580-588.

[54] Ö. Aktaş, F. Çeçen, Bioregeneration of activated carbon: A review, Int. Biodeterior. Biodegrad. 59 (2007) 257-272.

[55] D.E. Freedman, Biologically active filtration for treatment of produced water and fracturing flowback wastewater in the O\&G industry, Colorado School of Mines, Golden, CO (2014).

[56] R.W. Holloway, J. Regnery, L.D. Nghiem, T.Y. Cath, Removal of trace organic chemicals and performance of a novel hybrid ultrafiltration-osmotic membrane bioreactor, Environ. Sci. Technol. 48 (2014) 10859-10868.

[57] T.Y. Cath, A.E. Childress, M. Elimelech, Forward osmosis: Principles, applications, and recent developments, J. Membr. Sci. 281 (2006) 70-87.

[58] H. Strathmann, Membrane separation processes, J. Membr. Sci. 9 (1981) 121-189.

[59] B.D. Coday, P. Xu, E.G. Beaudry, J. Herron, K. Lampi, N.T. Hancock, T.Y. Cath, The sweet spot of forward osmosis: Treatment of produced water, drilling wastewater, and other complex and difficult liquid streams, Desal. 333 (2014) 23-35. 
[60] P. Xu, C. Bellona, J.E. Drewes, Fouling of nanofiltration and reverse osmosis membranes during municipal wastewater reclamation: Membrane autopsy results from pilot-scale investigations, J. Membr. Sci. 353 (2010) 111-121.

[61] Y. Yoon, P. Westerhoff, S.A. Snyder, E.C. Wert, Nanofiltration and ultrafiltration of endocrine disrupting compounds, pharmaceuticals and personal care products, J. Membr. Sci. 270 (2006) 88-100.

[62] M. Mulder, Basic principles of membrane technology, 2, Kluwer Academic Publishers, Dordrecht, Netherlands, 2001.

[63] S.M. Santos, M.R. Wiesner, Ultrafiltration of water generated in oil and gas production, Water Environ. Res. (1997) 1120-1127.

[64] Y. He, Z.-W. Jiang, Technology review: Treating oilfield wastewater, Filtr. Separat. 45 (2008) 14-16.

[65] S. Mondal, S.R. Wickramasinghe, Produced water treatment by nanofiltration and reverse osmosis membranes, J. Membr. Sci. 322 (2008) 162-170.

[66] M. Melo, H. Schluter, J. Ferreira, R. Magda, A. Júnior, O. de Aquino, Advanced performance evaluation of a reverse osmosis treatment for oilfield produced water aiming reuse, Desal. 250 (2010) 1016-1018.

[67] P. Xu, J.E. Drewes, Viability of nanofiltration and ultra-low pressure reverse osmosis membranes for multi-beneficial use of methane produced water, Sep. Purif. Technol. 52 (2006) 67-76.

[68] S. Alzahrani, A. Mohammad, N. Hilal, P. Abdullah, O. Jaafar, Comparative study of NF and RO membranes in the treatment of produced water-Part I: Assessing water quality, Desal. 315 (2013) 18-26.

[69] C.H. Webb, L. Nagghappan, G. Smart, J. Hoblitzell, R. Franks, Desalination of oilfieldproduced water at the San Ardo Water Reclamation Facility, CA, SPE Western Regional Meeting, San Jose, CA, March 24-26, 2009.

[70] A. Santos, S. Judd, The commercial status of membrane bioreactors for municipal wastewater, Separ. Sci. Technol. 45 (2010) 850-857.

[71] G.-d. Kang, Y.-m. Cao, Application and modification of poly(vinylidene fluoride) (PVDF) membranes - A review, J. Membr. Sci. 463 (2014) 145-165.

[72] APHA, Standard methods for the examination of water and wastewater (2012) Washington, DC, APHA. 
[73] M. Stahlschmidt, J. Regnery, A. Campbell, J.E. Drewes, Application of 3Dfluorescence/PARAFAC to monitor the performance of managed aquifer recharge facilities, J. Water Reuse Desal. (2015)

[74] T. Panswad, C. Anan, Impact of high chloride wastewater on an anaerobic/anoxic/aerobic process with and without inoculation of chloride acclimated seeds, Water Res. 33 (1999) $1165-1172$.

[75] P. Vuoriranta, S. Remo, Bioregeneration of activated carbon in a fluidized GAC bed treating bleached kraft mill secondary effluent, Water Sci. Technol. 29 (1994) 239-246.

[76] X. Zhao, Y. Wang, Z. Ye, A.G. Borthwick, J. Ni, Oil field wastewater treatment in biological aerated filter by immobilized microorganisms, Process Biochem. 41 (2006) 1475-1483.

[77] S. Delin, W. Jianlong, L. Kaiwen, Z. Ding, Kinetic performance of oil-field produced water treatment by biological aerated filter, Chin. J. Chem. Eng. 15 (2007) 591-594.

[78] M. Mulder, Basic principles of membrane technology, 2, Springer, Netherlands, 1996.

[79] M.H. Plumlee, J.-F. Debroux, D. Taffler, J.W. Graydon, X. Mayer, K.G. Dahm, N.T. Hancock, K.L. Guerra, P. Xu, J.E. Drewes, Coalbed methane produced water screening tool for treatment technology and beneficial use, J. Unconv. Oil Gas Res. 5 (2014) 22-34.

[80] K. Boussu, Y. Zhang, J. Cocquyt, P. Van Der Meeren, A. Volodin, C. Van Haesendonck, J. Martens, B. Van der Bruggen, Characterization of polymeric nanofiltration membranes for systematic analysis of membrane performance, J. Membr. Sci. 278 (2006) 418-427.

[81] M. Scholz, R. Martin, Ecological equilibrium on biological activated carbon, Water Res. 31 (1997) 2959-2968.

[82] D.R. Simpson, Biofilm processes in biologically active carbon water purification, Water Res. 42 (2008) 2839-2848.

[83] K. Kim, B.E. Logan, Fixed-bed bioreactor treating perchlorate-contaminated waters, Environ. Eng. Sci. 17 (2000) 257-265.

[84] P. Le-Clech, V. Chen, T.A. Fane, Fouling in membrane bioreactors used in wastewater treatment, J. Membr. Sci. 284 (2006) 17-53.

[85] C.J. Harrison, Y.A.L. Gouellec, R.C. Cheng, A.E. Childress, Bench-scale testing of nanofiltration for seawater desalination, J. Environ. Eng. 133 (2007) 1004-1014.

[86] Z.A. Stoll, C. Forrestal, Z.J. Ren, P. Xu, Shale gas produced water treatment using innovative microbial capacitive desalination cell, J. Hazard. Mater. 283 (2015) 847-855. 
[87] W. Chen, P. Westerhoff, J.A. Leenheer, K. Booksh, Fluorescence excitation-emission matrix regional integration to quantify spectra for dissolved organic matter, Environ. Sci. Technol. 37 (2003) 5701-5710.

[88] K.G. Dahm, C.M. Van Straaten, J. Munakata-Marr, J.E. Drewes, Identifying well contamination through the use of 3-D fluorescence spectroscopy to classify coalbed methane produced water, Environ. Sci. Technol. 47 (2012) 649-656.

[89] B.S. Kelso, J.D. Stewart, K.K. Norberg, T.A. Hewett, Niobrara biogenic natural gas in the eastern DJ Basin, Colorado, Kansas, and Nebraska, The Mountain Geologist 43 (2006) 237-242. 